\title{
SAXIFRAGO FERDINANDI-COBURGI- SESLERIETUM ACTAROVII - A NEW ASSOCIATION FROM THE SUBALPINE BELT OF THE SLAVIANKA (ORVILOS) MTS. (BULGARIA)
}

\author{
Todor KARAKIEV ${ }^{1}$, Rossen TZONEV ${ }^{2}$
}

\begin{abstract}
The paper discusses the phytosociological and syntaxonomical position of the dry subalpine grasslands in the Slavianka (Alibutoush, Orvilos) Mts. (South-Western Bulgaria, Northern Greece). A new association Saxifrago ferdinandi-coburgi-Seslerietum actarovii ass. nova has been established as a result of the phytosociological study. It is considered as an endemic vegetation unit from the calcareous subalpine terrains in the Central Balkan Peninsula high mountains (SouthWestern Bulgaria, Former Yugoslav Republic of Macedonia, Northern Greece). The new syntaxon belongs to the alliance Edrajantho-Seslerion Horvat 1949. A comparison with related syntaxa from other calcareous mountains from Northern Greece and the Former Yugoslav Republic of Macedonia is discussed.

Keywords: dry calcareous grasslands, phytosociology, syntaxonomy, Slavianka Mts., vegetation, EdraianthoSeslerion Horvat 1949.

\section{Izvleček}

V članku avtorji obravnavajo fitosociološki in sintaksonomski položaj suhih subalpinskih travnikov v gorovju Slavjanka (Alibutoush, Orvilos) (jugozahodna Bolgarija, severna Grčija). Kot rezultat fitocenoloških raziskav so opisali novo asociacijo Saxifrago ferdinandi-coburgi-Seslerietum actarovii ass. nova. Obravnavajo jo kot endemično vegetacijsko enoto iz subalpinskega pasu visokih gora v srednjem delu Balkanskega polotoka (jugozahodna Bolgarija, Makedonija, severna Grčija). Novoopisani sintakson uvrščajo v zvezo Edrajantho-Seslerion Horvat 1949. Sintakson so primerjali s sorodnimi sintaksoni iz drugih apneniških gora iz severne Grčije in Makedonije.

Ključne besede: suhi travniki na apnencu, fitosociologija, sintaksonomija, gorovje Slavjanka, vegetacija, Edrajantho-Seslerion Horvat 1949.
\end{abstract}

\section{INTRODUCTION}

The subalpine region of the Slavianka (Orvilos) Mts. (South-western Bulgaria, Northern Greece) (Figure 1) comprises the highest part of the mountain between 1900 and 2212 m including the highest peak - Gotzev Vruh /Alibotus. It covers an area of approximately $15 \mathrm{sq} . \mathrm{km}$. The region represents a karstic marble area facing north-east, north and north-west. There are many caves and precipices in the region, which have resulted from the karstic processes. The calcareous rocks cover $100 \%$ of the territory. The climate is transitional Mediterranean with an important mountain influence, especially in the investigated highest part of the mountain (Georgiev 1991, Velev 2002). The Slavianka Mts. (besides Southern Pirin) are the warmest Bulgarian mountains. The

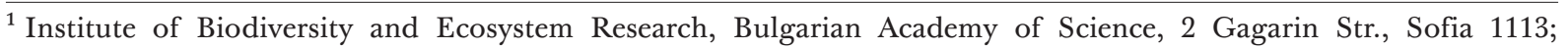
karakiev@abv.bg

${ }^{2}$ Department of Ecology and Environmental Protection, Sofia University “St. Kliment Ohridski”, Faculty of Biology, 8 Dragan Tzankov Blvd., Sofia 1164; rossentzonev@abv.bg
} 


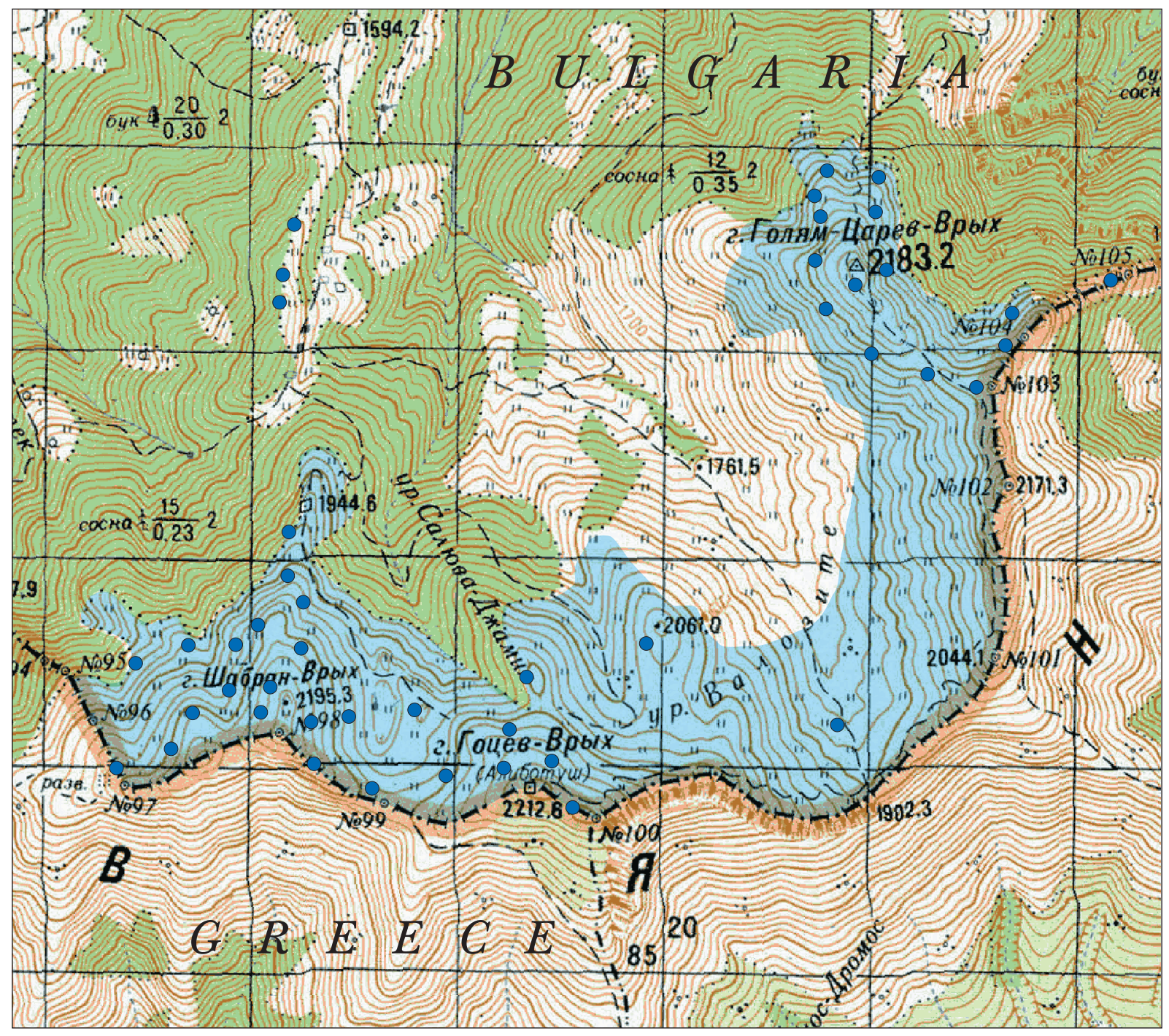

Figure 1: Topographic map of subalpine area of the Slavianka Mts. (M 1:50 000). In light blue is a study area, in dark blue points are areas of relevés.

Slika 1: Topografska karta subalpinskega območja gorovja Slavjanka (M 1: 50 000). Svetlo modro je prikazano obravnavano območje, temnomodre točke pa predstavljajo lokacije popisov.

permanent snow cover on the highest mountain parts continues only 90-100 days, while in Northern Pirin - 150 days (Vaptzarov et al.1989).

From a geobotanical point of view, the Slavianka Mts. belong to the Slavianka Mountain District - part of the Illyric (Balkan) province of the European deciduous forest region (Bondev 2002). The Slavianka Mts. are a very rich in endemic species. Bondev (2002) indicates 44 species - 38 Balkan and 6 local Bulgarian endemics.

Some data for the floristic diversity, phytogeography and vegetation of the Slavianka Mts. can be found in the works of Stojanoff (1922); Stojanov \& Stefanoff (1922) and Dryanovski (1934).
In the mountains of Northern Greece and the Former Yugoslav Republic of Macedonia, similiar herbaceous communities as in Slavianka Mts. are described, using the Braun-Blanquet methodology. There are no descriptions of such communities from Bulgaria so far. The most similar phytocoenoses in Bulgaria are described in the Pirin Mts. only by Simon (1958) and Mucina et al. (1990). The phytocoenoses described by Simon (1958) are typical alpine ones, while there is no alpine belt on the Slavianka Mts. The alpine and subalpine communities on calcareous screes, rock fissures and snow beds, described by Mucina et al. (1990) on the Pirin Mts. belong to 
the classes Thlaspietea rotundifolii Braun-Blanquet 1948, Asplenietea trichomanis (Braun-Blanquet in Meier et Braun-Blanquet 1934) Oberd. 1977 and Salicetea herbaceae Braun-Blanquet 1947. Only one association (Hieracio pannosi-Caricetum kitaibelianae Mucina et al. 1990) among them has some similiarities to the grasslands in the Slavianka Mts.

\section{METHODS}

The principles and methods of the Zürich-Montpellier School (Braun-Blanquet 1964, MuellerDombois \& Ellenberg 1974, Westhoff \& Maarel 1973) were applied. We used plot size of $10 \times 10$ $\mathrm{m}$ and as a result of the sampling 46 relevés were made. At each sampling plot, a complete list of the present species (vascular plants) was recorded, together with their cover-abundance value according to the 7-degree Braun-Blanquet scale (BraunBlanquet 1932). Eight out of 46 relevés dropped out as a result of the cluster analysis made in the SYN-TAX program (Figure 2). The diagnostic table includes 38 relevés (Table 1). They repre- sent the new syntaxon described in this article. 8 relevés were not included in the phytocoenologic analysis, because they were not typical. Most of the excluded relevés were dominated by Festucopsis sancta. They have been made at a lower altitude - in the open calcareous areas in the coniferous belt of Pinus heldreichii. To facilitate the statistical computer programs the scale of Braun-Blanquet was used, only transformed into ordinal numbers (Westhoff \& Maarel 1979). The computer software TurboVeg (Hennekens \& Schaminée 2001) was used for digitalizing and storing the data. The sorting of the relevés was made in JUICE software (Tichý 2002). For the purpose of the numerical classification the TWINSPAN method (Hill 1979) was applied, integrated in JUICE software. The results of the TWINSPAN analysis were compared using cluster analysis according to the computer program SYN-TAX (Podani 2002). The average linkage method (UPGMA) was used and floristic similarity between relevés was evaluated according to the Horn index (Krebs 1999). This index was used also for assessment of similarity among the closest associations. Both dendrograms are presented in the paper (Figure 3).

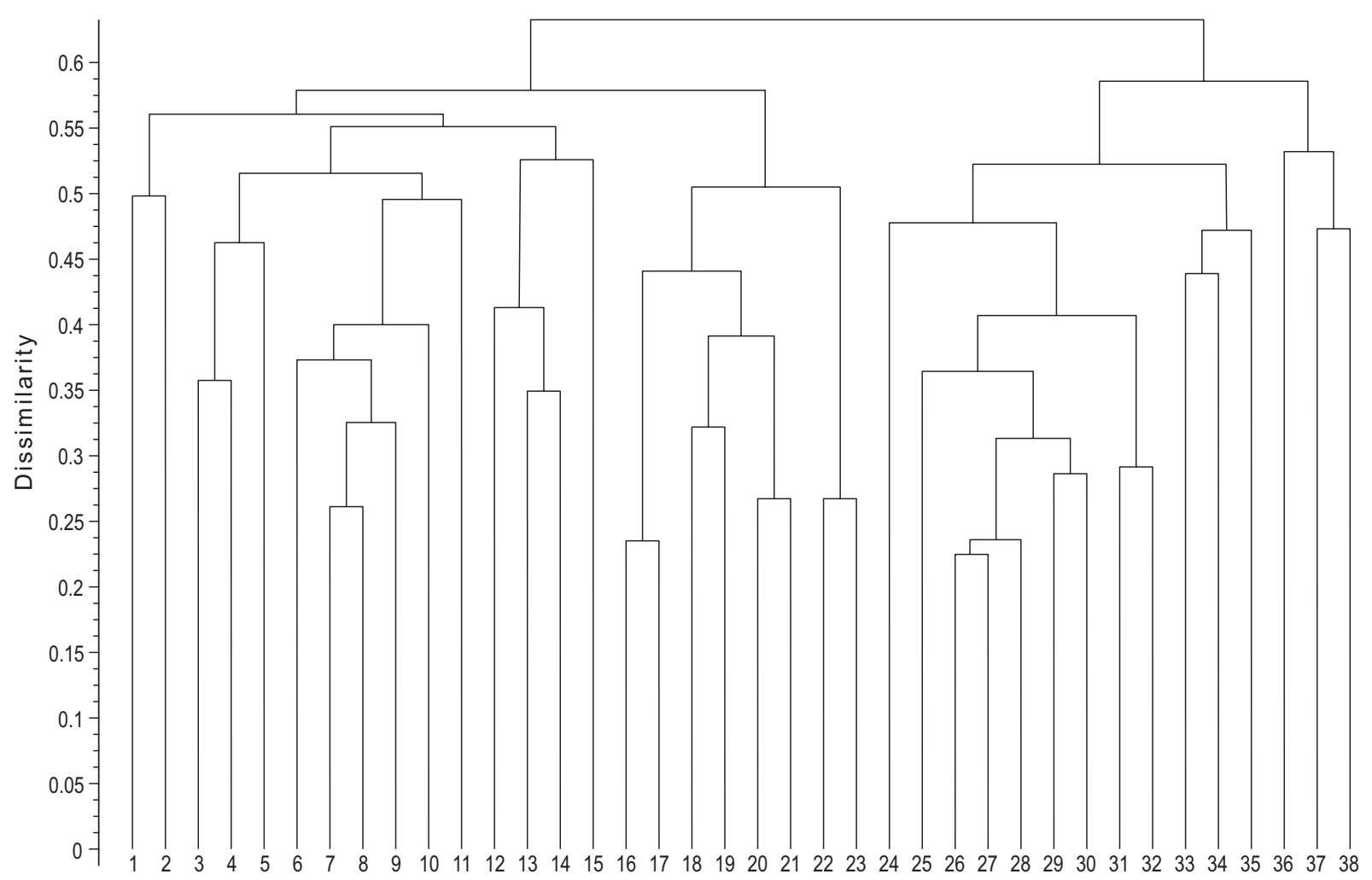

Figure 2: Cluster analysis of the new association - the dendrogram. Slika 2: Klastrska analiza in dendrogram nove asociacije. 


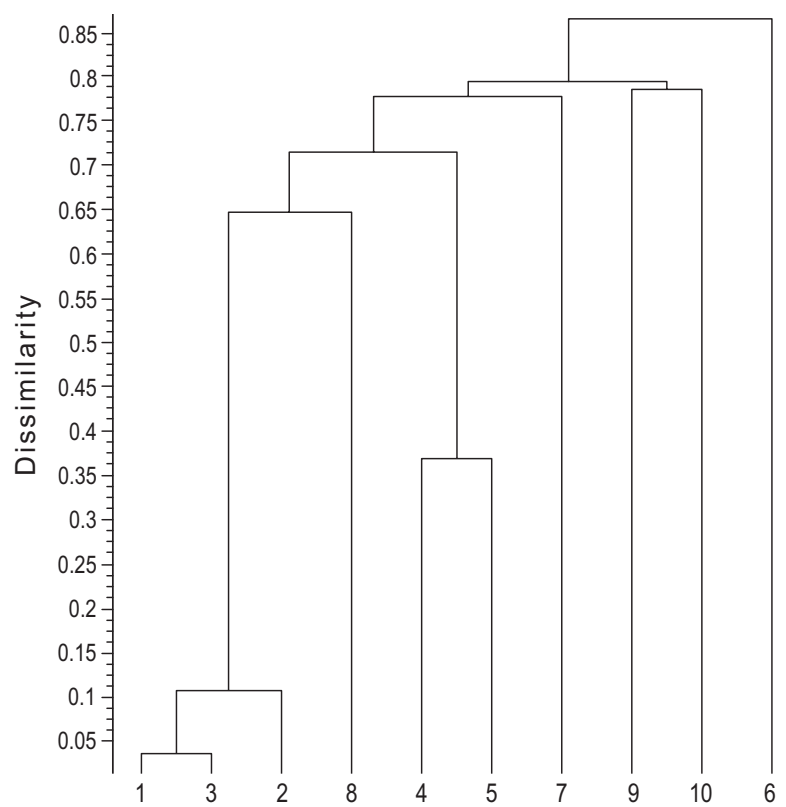

Figure 3: Cluster analysis of the most similiar associations to the new association.

Slika 3: Klastrska analiza najbolj podobnih asociacij in obravnavane asociacije.

1. Ass. Saxifrago ferdinandi-coburgi-Seslerietum achtarovii subass. typicum ; 2. Ass. Saxifrago ferdinandi-coburgi - Seslerietum achtarovii subass. violetosum perinensis, 3 . The new association - total constancy (Nova asociacija-stalnost); 4. Ass. Helianthemo - Seslerietum Horvat 1960; 5. Ass. Edraiantho - Helianthemum balcanici Horvat 1935; 6. Ass. Seslerio achtarovii-Festucetum variae Karagiannikidou et al. 2001; 7. Ass. Agropyro sancti - Centauretum parilicae Quezel 1989; 8. Ass. Violo delphinanthae - Saxifragetum ferdinandi-coburgi Quezel 1989; 9. Ass. Astragalo pungentis - Caricetum kitaibelianae Karagiannikidou 1994; 10. Ass. Hieracio-Caricetum kitaibelianae Mucina et al. 1990.

The synoptic similarity was evaluated using also PCo Analysis (Figure 4). Horn's index was also used for the PCo Analysis (Podani 2002).

The diagnostic species of published syntaxa were identified according to Horvat et al. (1974) and other referenced literature. The syntaxa's names and the names of their authors are given according to the International Code for Phytosogiologial nomenclature (Weber et al. 2000). The names of the plant taxa are given according to Delipavlov et al. (2003). The geographical elements of the taxa are given according to Asyov et al. (2006) except for the subspecies for which there are no data available in it. They are given according to Meusel et al. (1965). The plant lifeforms of the species are given using the classification of Raunkiaer (1934).

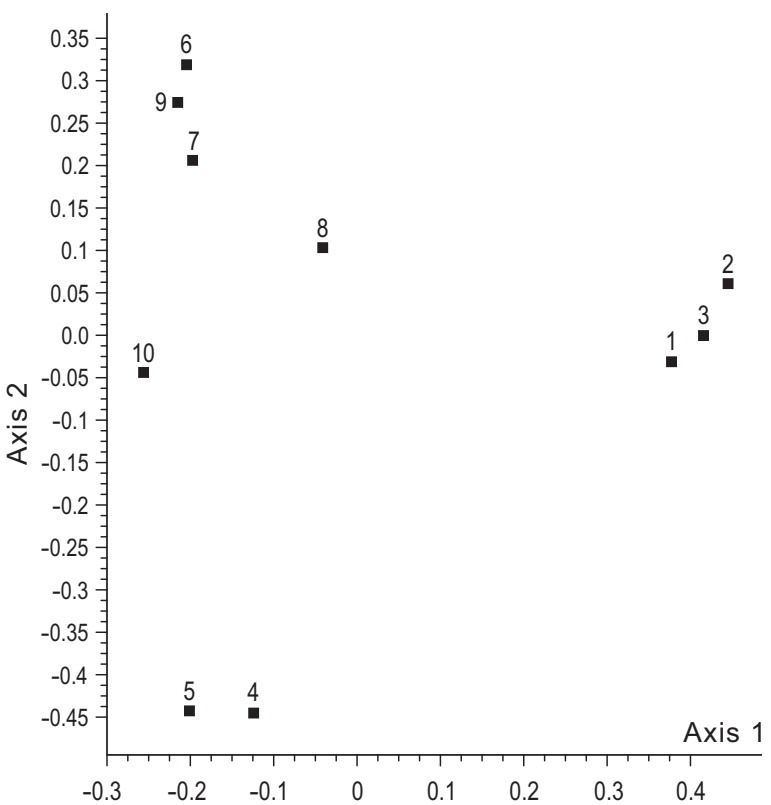

Figure 4. PCoA analysis of the most similiar associations to the new association.

Slika 4: Analiza PCoA najbolj podobnih asociacij in obravnavane asociacije.

1. Ass. Saxifrago ferdinandi-coburgii - Seslerietum achtarovii subass. typicum; 2. Ass. Saxifrago ferdinandi-coburgii-Seslerietum achtarovii subass. violetosum perinensis, 3 . The new association - total constancy (Nova asociacija-stalnost); 4. Ass. Helianthemo - Seslerietum Horvat 1960; 5. Ass. Edraiantho Helianthemum balcanici Horvat 1935; 6. Ass. Seslerio achtarovii - Festucetum variae Karagiannikidou et al. 2001; 7. Ass. Agropyro sancti - Centauretum parilicae Quezel 1989; 8. Ass. Violo delphinanthae - Saxifragetum ferdinandi-coburgi Quezel 1989; 9. Ass. Astragalo pungentis-Caricetum kitaibelianae Karagiannikidou 1994; 10. Ass. Hieracio- Caricetum kitaibelianae Mucina et al. 1990.

\section{RESULTS}

The analysis of the sampled phytosociological material manifests the existence of one single association, which covers the entire territory of the highest part of the Slavianka Mts.

The unique vegetation of the non-forest subalpine belt of the Slavianka Mts. is presented by the association below. It belongs to the syntaxonomical hierarchical position given below:

Association Saxifrago ferdinandi-coburgi - Seslerietum actarovii ass. nova; nomenclatural type: Table 1, Rel. 7 holotypus hoc loco

Table 1, rel.1-38, Table2, column 3.

Characteristic taxa: Sesleria rigida subsp. achtarovii; Saxifraga ferdinandi-coburgi; Galium demis- 
sum subsp. demissum; Centaurea napulifera subsp. nyssana; Pedicularis orthantha; Centaurea parilica.

Differential taxa: Sempervivum leucanthum; Anthyllis aurea; Petkovia orphanidea; Astragalus depressus; Viola perinensis; Vaccinium myrtillus; Primula elatior subsp. intricata; Crocus veluchensis.

Dominant taxa: Sesleria rigida subsp. achtarovii; Carex kitaibeliana.

Constant taxa: Sesleria rigida subsp. achtarovii; Carex kitaibeliana; Rhodax canus; Funiperus pigmaea.

The syntaxonomic position:

Class Elyno-Seslerietea Braun-Blanquet 1948

Order Onobrychido-Seslerietalia Horvat 1949

Alliance Edraiantho-Seslerion Horvat 1949

Association Saxifrago ferdinandi-coburgi -

Seslerietum actarovii ass. nova

Subassociation typicum

Subassociation violetosum perinensis subass. nova

We established a new association designated as Saxifrago ferdinandi-coburgi-Seslerietum actarovii ass. nova, consisting of two subassociations: subass. typicum and subass. violetosum perinensis subass. nova. The phytocoenoses of the new association are characterized by the presence of vicariant species, by the extent of Mediterranean and Pontic-continental phytogeographical influence and by the number of endemic taxa (Figure 5).

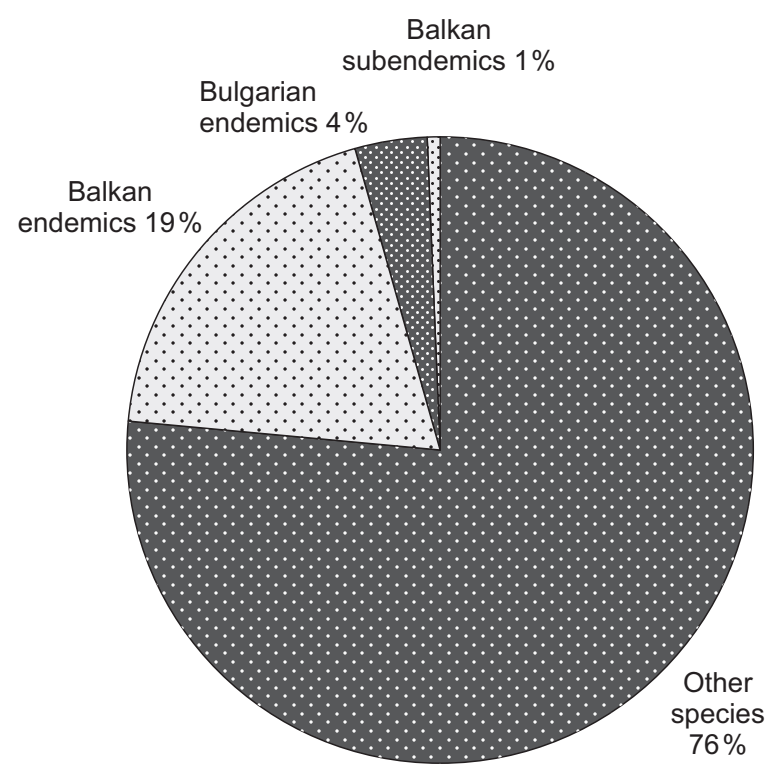

Figure 5: The participation of endemics and subendemics in the phytocoenoses of the new association.

Slika 5: Delež endemitov in subendemitov v sestojih novopisane asociacije.
There is a main "nucleus" of species common to several associations described in Northern Greece (Falakron, Menikion and Pangeon Mts.) and Southern Macedonia (Yakupica Mts.). An essential variance between the individual associations exists concerning their complex of diagnostic species. Saxifrago ferdinandi-coburgi-Seslerietum actarovii belongs to Elyno-Seslerietea, OnobrychidoSeslerietalia, Edrajantho-Seslerion and confirms the presence of these syntaxa in Bulgaria. But it can be defined more accurately after future detailed studies are made of similar vegetation in Bulgaria including the Pirin Mts.

The high level of constant presence of the paleoendemic Saxifraga ferdinandi-coburgi underlines the connection of the flora and the vegetation in the Slavianka Mts. with the Rilo-Rhodopean center of endemism. This species occurs in some of the highest mountains in Northern Greece and Macedonia as well. It is comparatively rare there and in fact does not have an essential participation in the grassland vegetation, with the exception of the Falacron Mts. (Quezel 1989). Saxifraga ferdinandi-coburgi exists in the associations Leontopodio-Potentilletum stojanovii and Hieracio Caricetum kitaibelianae (Simon 1958, Mucina et al. 1990) as well. It was indicated by the authors as a diagnostic to class Festuco-Seslerietea (syn. Elyno-Seslerietea). These communities, however, are included in the class Asplenietea trichomanes (Braun-Blanquet in Meier et BraunBlanquet 1934) Oberd. 1977.

Other diagnostic species, which emphasize the connection of the flora and the vegetation of the Slavianka Mts. with the northern (Rila and Rhodopi Mts.) center of endemism, are: Pedicularis orthantha (41\%); Sempervivum leucanthum (44\%). These two species, however, are not of diagnostic value in the described syntaxa from the mountains of Northern Greece and Macedonia (Horvat et al. 1974; Quezel 1989; Karagiannakidou 1994). The diagnostic species characterizing the influence of the Greek-Macedonian center of endemism, including the Slavianka Mts. and the mountains in Northern central Greece, are Galium demissum subsp. demissum (56 \%); Centaurea parilica (29\%), Petkovia orphanidea (25\%) etc.

Following the ecological specificities of the environmental conditions, the analysis differentiated two groups of phytocoenoses, which were grouped in sub-associations. The typical subassociation (subass. typicum), nomenclatural type is identical with the nomenclatural type of the asso- 


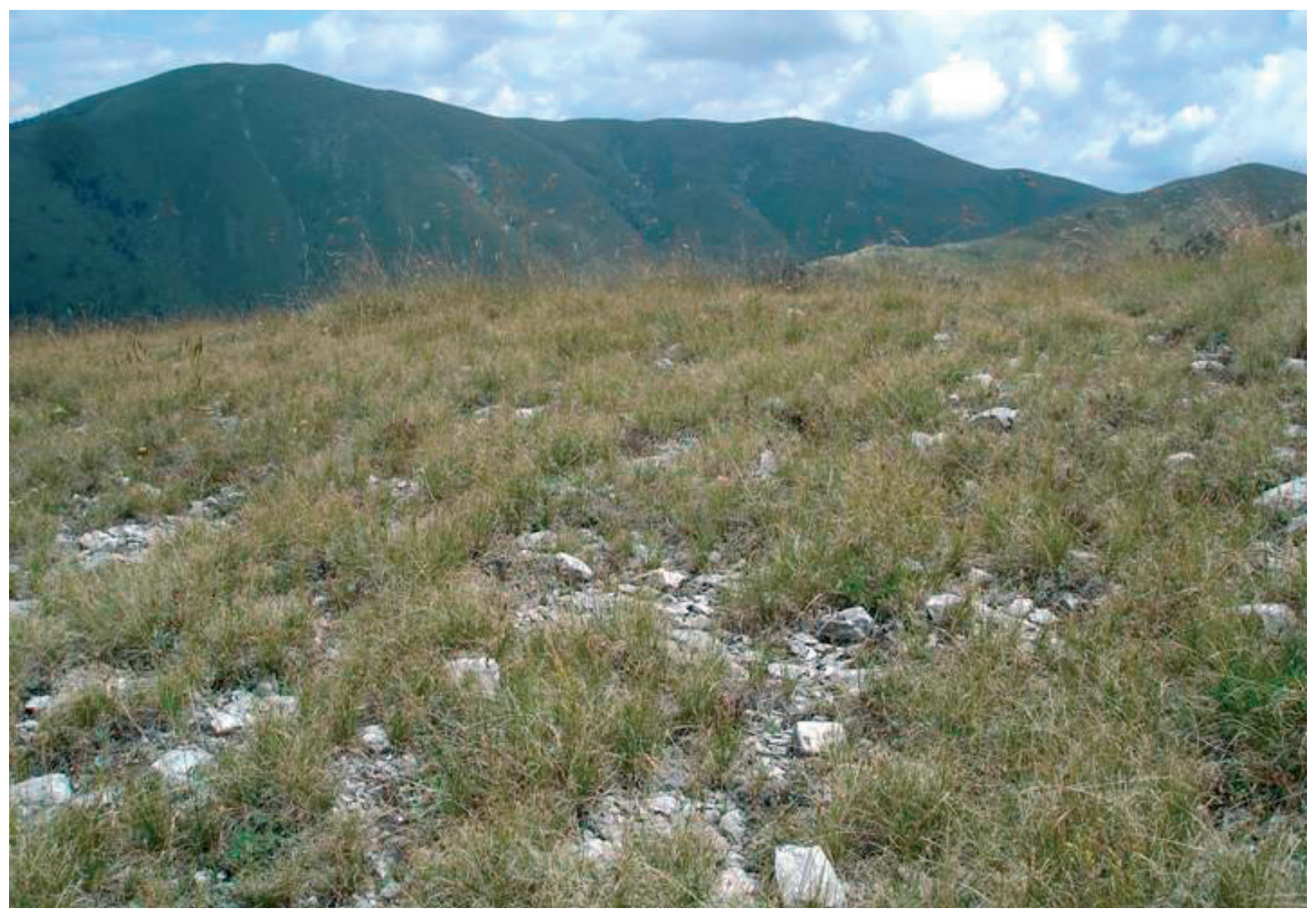

Figure 6: Picture of the new association: Saxifrago ferdinandi-coburgi-Seslerietum actarovii subass. typicum. Slika 6: Fotografija sestoja nove asociacije Saxifrago ferdinandi-coburgi-Seslerietum actarovii subass. typicum.

ciation (Figure 6) It is distributed in places with very thin and not fertile soil. The phytocoenoses have a comparatively small coverage due to the emerging rocks including rock pieces of different size. Some diagnostic species to the association are chasmophytes. They have a higher frequency in comparison with some other ecological groupes. Such species are: Petkovia orphanidea (43\%); Sempervivum leucanthum (74\%); Paronychia kapela (65\%); Globularia cordifolia (26\%); Achillea ageratifolia (44\%) etc. Since the phytocoenoses of the typical subassosiation are found on open rocky and stony places, the tufts of species from Poaceae and Cyperaceae families have smaller coverage.

The phytocoenoses of the second subassociation take the flat or grooved places, where rock debris accumulates and soil formation is initiated. The rains water stays longer in these places and the phytocoenoses are developed in more mesophilous conditions. The complex of species indicating the presence of better and richer soils, which are found frequently in this group of phytocoenoses, includes: Astragalus depressus (80 \%);
Vaccinium myrtillus (60\%); Primula elatior (60\%); Crocus veluchensis (27\%); Viola perinensis (53\%). Some of these species are spring ephemeroides, such as Corydalis solida, Crocus veluchensis, Primula elatior and Muscari botryoides. They grow in places sufficiently wet, because the moisture from the rain retained when it penetrates the limestone karstic rocks. The diagnostic species of this group is the local endemic for the Pirin Mts., Slavianka Mts. and Falacron Mts. The name-giving taxon is Viola perinensis - typical for these conditions. The subassociation: violetosum perinensis subass. nova. hoc loco, nomenclatural type: Table 1, rel. 9, holotypus (Figure 7).

\section{DISCUSSION}

The studied vegetation of the subalpine zone of the Slavianka Mts. is found on open, rocky places with poor soils. The soils are rendzinas - shallow humus-carbonate ones - which embrace little pieces of the limestone basic rock (Ninov 2002). 


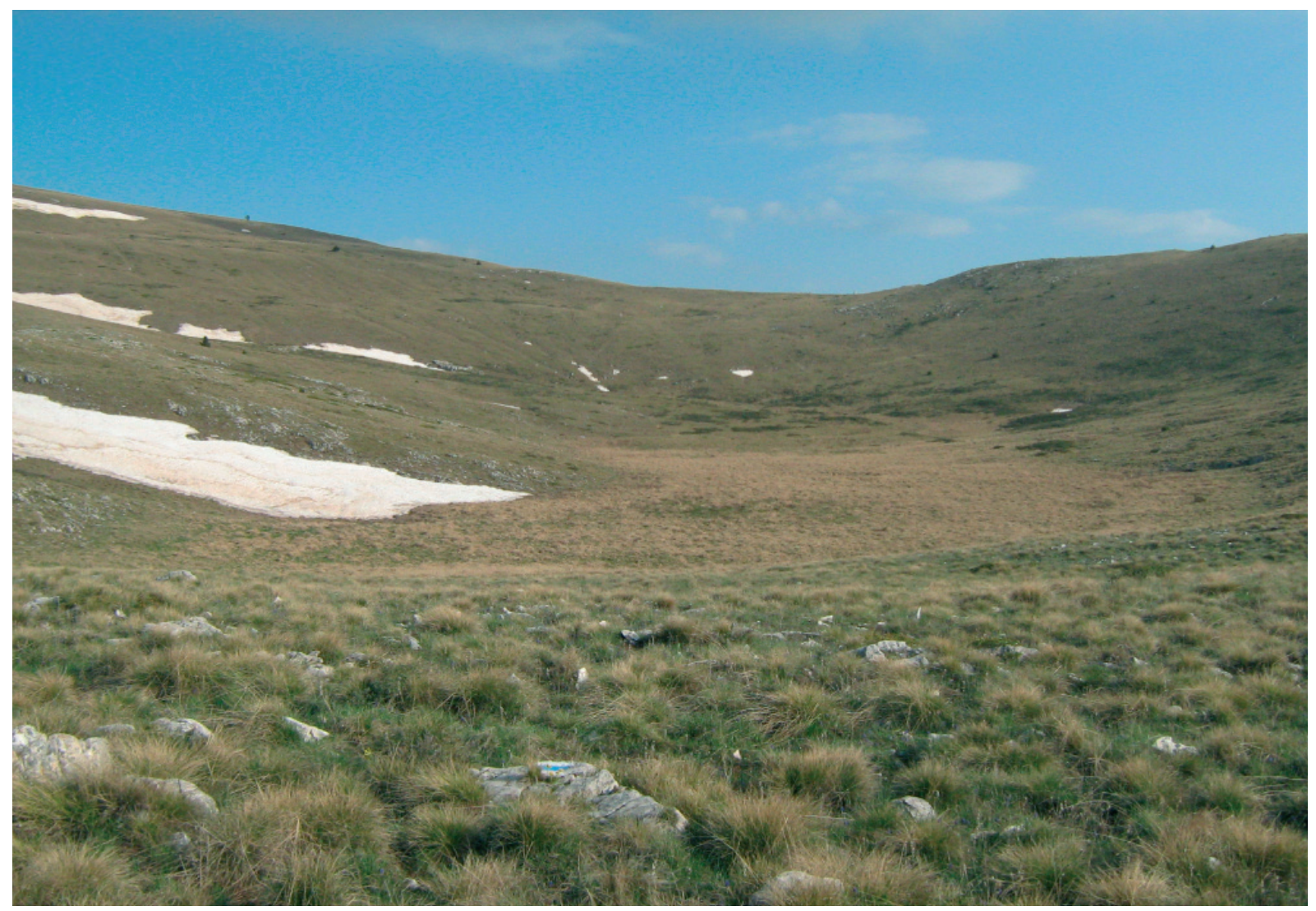

Figure 7: Picture of the new association Saxifrago ferdinandi-coburgi-Seslerietum actarovii subass. violetosum perinensis. Slika 7: Fotografija sestoja nove asociacije Saxifrago ferdinandi-coburgi - Seslerietum actarovii subass. violetosum perinensis.

The structure of the phytocoenoses is from open to almost closed, as the total vegetation coverage varies from $20 \%$ to $90 \%$. The mean coverage is $58 \%$. The investigated phytocoenoses grow most frequently on slopes with north, north-east or north-west exposition. The emerging bedrock can be found at the surface in many places as large fragments of different sizes, from gravel to main rocks. In some sites the bare rock covers more than $70 \%$ of the ground.

The phytocoenoses are characterized by a poor presence of trees and shrubs, excluding some solitary specimens, Juniperus nana, Pinus cheldreichii and Chamaecytisus absinthioides etc (Figure 8). They are typical for the upper limit of the forests and lower zone of the subalpine belt in the Slavianka Mts. The investigated phytocoenoses are not very rich in species. The number of species per relevé varies from 10 to 35 and the average number is 15. The main dominants are grasses (Poaceae), but also some species from the families Primulaceae, Campanulaceae, Gentianaceae. But frequent are also chamaephytes, such as Rodax canus (Cistacea).

\section{SYNTAXONOMICAL POSITION OF THE GRASSLANDS IN THE SLAVIANKA MTS.}

The phytogeographical, floristic and phytocoenological peculiarities of the Slavianka Mts. raise a question about the ordering of new associations to highest ranking syntaxa. The closest syntaxa from the Falacron Mts. are classified by Quezel (1989) as belonging to the class DaphnoFestucetea Quezel 1964 (Quezel 1967). This class has been described by him in the mountains of the thermo-Mediterranean zone of Greece. This decision about the grassland communities of the orophyte grassy belt is presented in the works on the Pangeon Mts. (Karagiannakidou et al. 2001) and Menikion Mts. (Karagiannakidou 1994). Shreiber (1998) supposes that the oro-Mediterranean grassland vegetation there belongs to the class Festuco-Brometea. He makes this conclusion because of the great differences between the grassland vegetation in the Falacron Mts. and the 


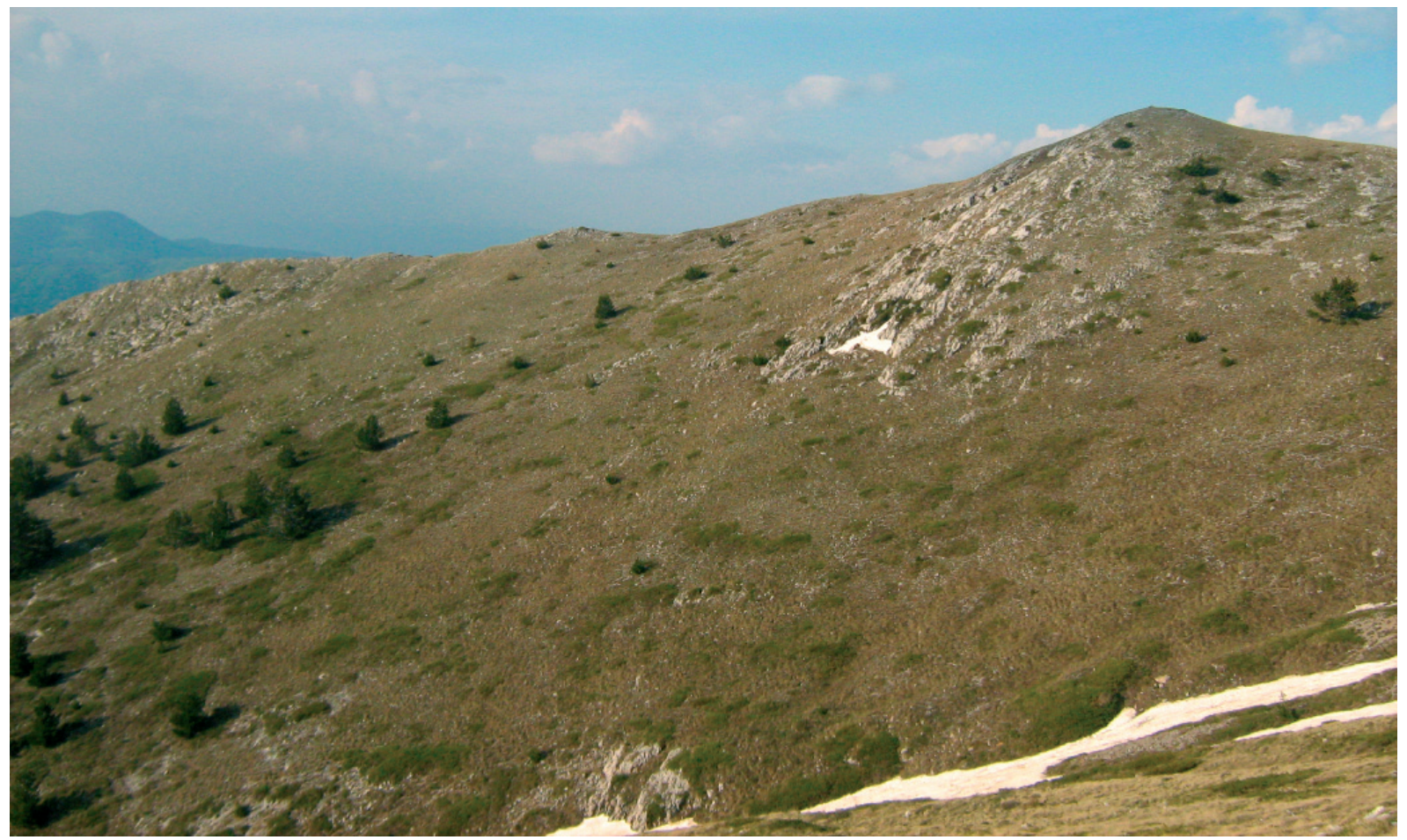

Figure 8: Picture of the subalpine belt of the Slavianka Mts - participation of trees (Pinus heldreichii) and shrubs (Juniperus pygmaea, Chamaecytisus absinthioides).

Slika 8: Fotografija subalpinskega pasu gorovja Slavjanka - sestoji dreves (Pinus heldreichii) in grmov (Juniperus pygmaea, Chamaecytisus absinthioides).

vegetation of the Greek mountains situated further South as well as the strong continental influence, expressed in the appearance of communities, dominated by species of the Poaceae family. They are characteristic of the forest-steppe landscapes in South-Eastern Europe, but he cannot decide on the alliance and the orders in which to place the described communities. On the basis of the predominance of diagnostic species from the class Daphno-Festucetea Quezel 1964 (Quezel 1967) in the subalpine grassland communities in the Menikion Mts., Pangeon Mts. and Falacron Mts., Karagiannakidou et al. (2001) reject this decision. At the same time, they discuss the great presence of many elements of the class Elyno-Seslerietea Braun-Blanquet 1948. According to them, the southern limit of the class on the Balkan Peninsula includes also Northern Greece. Karagiannakidou et al. (2001) accept the presence of elements from three classes in these mountains. It is a result of their intermediate location between central-European and sub-Mediterranean influence. Similiar are the phyto-geographical conclusions made by Stefanović (1996) using the floristic analyses. This influence is determined by the geographical position of the place and their altitude. For example, Raus (1987) on the basis of data given by Quezel (1967) for association Anthyllido auraea-Achilleetum ageratifoliae (Daphno-Festucetea) from the highest parts of Mt. Olympus classifies it as belonging to the class $E l$ yno-Seslerietea. According to Karagiannakidou et al. (2001), the question concerning the borders of distribution and the contact areas of vegetation communities, belonging to the classes DaphnoFestucetea Quezel 1964, Elyno-Seslerietea BraunBlanquet 1948 and Festuco-Brometea Braun-Blanquet \& Tüxen ex Braun-Blanquet 1949, should be answered after intensive phytocoenological studies in all mountains of Northern Greece, including the Orvilos (Slavianka) Mts.

It should be noted that one of the most characteristic special features of the class Daphno-Festucetea is the high occurrence of chamaephytes. Very often among them dominates Astragalus angustofolius subsp. pungens, which in the Slavianka Mts. does not play a significant role. For example, for the associations described by Karagiannakidou et al. (2001) from the Pangeo Mts. an average of between 20 and $32 \%$ chamaephytes 
are given in the biological spectrum of those associations. In the recently described association from the Slavianka Mts., the chamaephytes are under $10 \%$ (Figure 9). This fact, together with the northern geographical location as well as the floristic and phytogeographical influence of the Rilo-Rhodopean Mountain massif, which is stronger here, defines the belonging of the associations from the Slavianka Mts. most likely to class Elyno-Seslerietea Braun-Blanquet 1948, order Onobrychido-Seslerietalia Horvat 1949, alliance Edrajantho-Seslerion Horvat 1949.

The classification of the associations of alpine vegetation on limestone areas in South-Eastern Europe only to class Elyno-Seslerietea Braun-Blanquet 1948 is also subject of discussions. For example, Petrík et al. (2005) dispute the opinion of Oriolo (2001) that all limestone alpine and subalpine communities in Southern and Central Europe belong to the class Elyno-Seslerietea. They consider as more acceptable the approach of $\mathrm{Oh}$ ba (1974), who in the Japanese mountains regards the typical, and sometimes poor in species alpine communities, as belonging rather to the class Carici rupestris-Cobresietea bellardii Ohba 1974. After their analyses, Petrík et al. (2005) separated alpine and sub-alpine grassland vegetation on calcareous and neutral bedrock in the Tatra Mts. into two classes. As an essential difference between the classes Elyno-Seslerietea and Carici rupestris-Cobresietea bellardii in the mountains of Southern and Central Europe, the authors indicated the presence of many endemic taxa in the first, and the predomination of species with circum-boreal and arctic-alpine distributions in the second. The arctic-alpine group includes species like Saxifraga oppositifolia, S. paniculata, Silene acaulis, Carex rupestris, Elyna bellardii and others. If we accept this separation, the question arises whether it is right to put the closest to the plant communities from the Slavianka Mts. alpine and sub-alpine communities into the Pirin Mts. (Anthyllio-Seslerion klasterskyi Simon 1958) within Edrajantho-Seslerion of Horvat et al. (1974) or, as proposed by Tzonev et al. (2009), to join them to the alliance Oxytropido-Elynion Braun-Blanquet 1949 of Carici rupestris-Kobresietea bellardii Ohba 1974. There are also some species from the group designated by Petrík et al. (2006) in the Pirin Mts., but on the other hand, the presence of many local endemics like Papaver degenii, Thymus perinicus, Festuca pirinica etc., confirms the decision of Horvat et al. (1974). It should be mentioned that the association de-

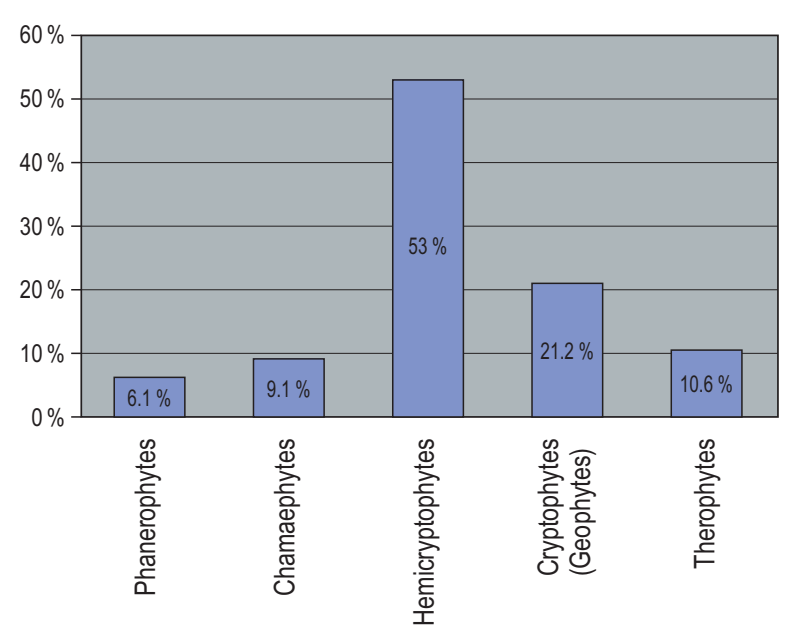

Figure 9: Spectrum of plant life-forms of the association Saxifrago ferdinandi-coburgi - Seslerietum achtarovii.

Slika 9: Deleži življenjskih oblik v asociaciji Saxifrago ferdinandi-coburgi - Seslerietum achtarovii.

scribed by Simon (1958), Elynetum pirinicum Simon 1958 nom. invalid (art. 34a), which is characterized by richness of mosses and lichens and poor species composition, was included into the alliance Oxytropidi-Elynion Braun-Blanquet 1949, described in the Alps. Later Rodwell et al. (2002) included the alliance Oxytropidi-Elynion Horvat 1949 into Carici rupestris-Kobresietea bellardii Ohba 1974. All these facts could lead to the conclusion that most alpine and subalpine grassland communities in Bulgaria on the limestone substrates belong to the class Elyno-Seslerietea. At the same time, the class Carici rupestris-Kobresietea bellardii probably includes not only communities with vascular plant species, but also communities rich in mosses and lichens. The vascular plants are Elyna bellardi, Carex rupestris and other in the alpine belt above $2500 \mathrm{~m}$ in the Pirin Mts. The investigated communities in the Slavianka Mts. should be included in the class Elyno-Seslerietea. This conclusion can become final decision after subsequent detailed studies of this vegetation in Bulgaria.

\section{COMPARISION OF THE GRASSLANDS IN SLAVIANKA WITH SIMILIAR COMMUNITIES ON THE BALKAN PENINSULA}

Some associations in Bulgaria are described in the Slavianka Mts. according to the dominant method. They are only named, without phyto- 
coenotic descriptions in detail. These are: Ass. Convolvulus suendermanii-Festucopsis sancta; Ass. Convolvilus suendermanii; Ass. Dryas octopetala; Ass. Festuca penzesii-Sesleria coerulea; Ass. Festuca penzessii-Stipa pulcherrima; Ass. Festuca penzesiiAstragalus angustifolius; Ass. Festucopsis sancta-Sesleria coerulea; Ass. Festucopsis sancta-Sesleria rigi$d a$; Ass. Festucopsis sancta-Stipa pulcherrima; Ass. funiperus pygmaea (Velchev \& Bondev 1984a, b).

As their names show, most of those associations are found at opened places in the forest belt, where there are ecological optimums of species like: Festucopsis sancta; Festuca penzesii; Convolvulus boissieri subsp. suendermanii.

The cluster dendrogram (Figure 3) and the PCoA (Figure 4) demonstrate the similarity between the syntaxa of the Slavianka Mts. and those of other mountains.

The association Hieracio-Caricetum kitaibelianae Mucina et al. 1990 is the closest in the Pirin Mts. to the studied vegetation. It belongs to the alliance Ramondion nathaliae Horvat ex Simon 1958 (order Potentilletalia causlescentis Braun-Blanquet 1926; class Asplenietea trichomanes (Braun-Blanquet in Meier et Braun-Blanquet 1934) Oberd. 1977). This association includes subalpine grassland communities on the marbles in the Northern Pirin Mts. The association described by Mucina et al. (1990) has several common species with the grasslands of the Slavianka Mts., such as Saxifraga ferdinandi-coburgi, Globularia cordifolia, Teucrium montanum, Paronichia kapela, Carex kitaibeliana, Rhodax canus, Achillea ageratifolia. Most of them have wide distribution in the calcareous mountains of the Balkan Peninsula. However the characteristic species do not occur in the investigated vegetation. These are Hieracium pannosum, Hypochaeris pelivanovici, Asperula suberosa, Carum rigidulum, Centaurea mannagettae, Allium minus, Micromeria cristata. Another difference is the presence of typical species for Asplenietea trichomanis as Asplenium ruta-muraria, Asplenium trichomanes, Kernera saxatilis, as well as the diversity from mosses and lichens.

The associations from the alliance EdraianthoSeslerion Horvat 1949 from some of the mountains in the Former Yugoslav Republic of Macedonia (FYROM) are close to the association in the Slavianka Mts. They inhabit open calcareous terrains, exposed to strong winds, on the high mountains mostly in the central part of the country. The association Helianthemo-Seslerietum Horvat 1960 from the Yakupitsa Mts. (Central Mace- donia) demonstrates the highest similarity to the association in the Slavianka Mts. This similarity presumes the existence of vicariant syntaxa, in spite of the presence of many common species: Globularia cordifolia (V); Paronychia kapela (V); Achilea ageratifolia (IV), Anthyllis aurea (II); Dryas octopetala (II); Carex kitaibeliana (V). Most of these species form one common "nucleus" (calciphytes, oro-Mediterranean species and glacial relicts) on all calcareous mountains in the region (South Western Bulgaria, Northern Greece, Macedonia). However, the taxa, which give the name to the association discussed here, Sesleria juncifolia (V) and Helianthemum scardicum (V), do not occur in Bulgaria.

Other species also differ from those in the Slavianka Mts: Edrajanthus graminifolius (V); Oxytropis urumovii (I); Carex ericetorum (I); Festuca rupicola (IV), Ranunculus oreophyllus (II). On the other hand, most of the endemic species from the Slavianka Mts. do not occur in the Yakupitsa Mts: Petkovia orphanidea; Centaurea parilica, Saxifraga ferdinandi-coburgi, Sesleria rigida subsp. achtarovii, Viola perinensis etc. One floristic similarity, besides the "nucleus" from the calciphytes mentioned above, to the other close association Edrajantho-Helianthemetum alpestris Horvat 1935, is the participation of Saxifraga ferdinandi-cobur$g i$, but with very low presence. Despite their belonging to the same class - Elyno-Seslerietea, other associations from FYROM and countries from Former Yugoslavia (see Horvat 1930; 1949, Horvat et al. 1974; Lakušić 1966, Rajevski 1990 etc.) do not demonstrate any close similarity. They have not been discussed here.

Phytocoenological researches on the Slavianka Mts. show the great similarity (Figure 3, 4) of the subalpine grasslands there to those on the Falacron Mts. (Bozdag) in Northern Greece (Quezel 1989; Shreiber 1998). This similarity is not so strong with the communities on the Menikion (Serski Bozdag) Mts. (Karagiannakidou 1994) and Pangeon (Kushnica, Parnar Dag) Mts. (Karagiannakidou et al. 2001). In the latter two mountains, some associations of grassland vegetation are described (Table 2). They show a certain similarity to, as well as some essential differences from the vegetation of the Slavianka Mts. The difference between the Slavianka Mts. and other Greek high mountains increases the closer these mountains are to the Mediterranean Sea. For example, around about the Pangeon Mts. (which are southernmost in the region), only one 
association has some similarities to the vegetation of the Slavianka Mts. - Seslerio achtaroviiFestucetum variae Karagiannakidou \& al. 2001. The other associations described by Karagiannakidou et al. (2001) have species diagnostic rather for the class Festuco-Brometea. The association Seslerio achtarovii-Festucetum variae (Karagiannakidou et al. 2001) has many common species with the phytocoenoses of the Slavianka Mts.: Sesleria rigida subsp. achtarovii, Astragalus angustifolius and Carex kitaibeliana. At the same time, it is possible to find some species which grow at lower altitude in the Slavianka Mts., such as Euphorbia amygdaloides, Carex humilis, Brachypodium pinnatum, Dianthus petraeus and others. Typically, there is the participation of some characteristic species for the xerothermic oak belt in the subalpine grasslands. This is due not only to the much lower altitude of the mountain - the highest peak Mati (Koznica) is at $1956 \mathrm{~m}$, but also to the strong Mediterranean influence, which leads to remission and aridization of the climate. That influence decreases northwards, but again it is much stronger than on the Slavianka Mts. In the vegetation of the Menikion Mts., only one association (Karagiannakidou 1994) includes phytocoenoses that are close to the grassland communities in the Slavianka Mts. - Astragalo pungentisCaricetum kitaibelianae (Karagiannakidou 1994). The phytocoenoses of this main association in the oro-Mediterranean zone of the mountain have species common with those in the Slavianka Mts.: Sesleria rigida, Carex kitaibeliana, Rhodax canus, Teucrium montanum, Petkovia orphainidea. At the same time, some of the local endemics of the Slavianka Mts. are missing on the Menikion Mts. (Centaurea parilica, Galium demissum subsp. demissum), as well as endemics from the center of endemism, situated north from the Slavianka Mts.: Sempervivum leucanthum, Pedicularis ortantha, Saxifraga ferdinandi-coburgi, Viola perinensis. On the other hand, vast (in comparison to the Slavianka Mts.) is the participation of Astragalus angustifolius. Many species could be found there, which do not occur in Bulgarian group of phytocoenoses (some of them do not occur in Bulgaria at all): Sempervivum marmoreum, Festuca macedonica, Thymus cherleriodes, Sesleria tenerrima, Dianthus petraeus.

The closest associations to the grassland vegetation of the oro-Mediterranean belt of the Slavianka Mts. are the ones described from the $\mathrm{Fa}$ lacron (Bozdag) Mts. These are the associations:
Agropyro sancti-Centaureetum parilicae and Violo delphinanthae-Saxifragetum ferdinandi-coburgii (Quezel 1989) and the community Anthyllis montana subsp. jacquini-Androsacae villosa (Shreiber 1998). The association Agropyro sancti-Centaureetum parilicae is spread at a lower altitude (1600-2020 m) than the Slavianka Mts. The diagnostic species: Festucopsis sancta, Centaurea parilica, Thymus thracicus, Onobrychis alba subsp. calcarea, Potentilla cinerea, Genista depressa, Origanum vulgare, Achillea ageratifolia, demonstrate a similarity to the communities with Festucopsis sancta in Bulgaria, occurring on open and rocky places in the Bosnian pine belt of the Slavianka Mts. Probably, due to the much stronger Mediterranean influence, some of the species occupying places at lower altitudes in the Slavianka Mts., in the Falacron Mts. have a phytocoenotical optimum at higher altitudes. This should be an object of additional research. A typical example for this phenomenon is the association Violo delphinanthae-Saxifragetum ferdinandi-coburgii Quezel 1989. This association is probably identical with the communities $A n$ thyllis montana subsp. jacquini-Androsacae villosa (Shreiber 1998), due to the great similarity of its floristic composition. The oro-Mediterranean grassland vegetation of the Slavianka Mts. shows considerable syntaxonomical similarity with two associations on the Falacron Mts. One main group of species persists at constant high level in the syntaxa of the two mountains: Rhodax canus, Globularia cordifolia, Carex kitaibelliana, Thymus thracicus, Petkovia orphanidea, Saxifraga ferdinandi-coburgi, Androsacae villosa, Achillea ageratifolia, Dryas octopetala. At the same time, probably because of the climatic influence and specifics of the center of endemism, some diagnostic species to the phytocoenoses of the Falacron Mts. do not play a significant role in the Slavianka Mts. ( $A n$ thylis montana subsp. jacquini) or generally they do not occur in the composition of grassland vegetation (Viola delphinantha, Festuca kortitnicensis). For example Viola delphinantha on the Slavianka Mts. is in the most northern part of its range of distribution. It can be found only in Parilski Dol Valley, where its individuals inhabit the stones as part of the composition of the chasmophytic vegetation in the forest belt. Festuca kortitnicensis and Festuca panciciana do not occur also in the Slavianka Mts. Characteristic is the difference in the participation of other grasses from Poaceae, which form a part and/or dominate in communities in the Falacron Mts. For example, the floristic 
composition of the association Festucopso sanctiCentauretum parilicae includes dominants similar to those on the Slavianka Mts., except Festucopsis sancta and Sesleria coeralns. But especially for Sesleria sp. it the following fact should be noted. The more complete floristic work of Karagiannakidou et al. (1995) on the Falakron Mts. mentions three other species from the genus (including Sesleria rigida subsp. achtarovii), but not Sesleria coerulans. This species has not been indicated on the Orvilos Mts. (see Karagiannakidou et al. 1995) - the Greek part of the mountains. Here we should emphazise that a similar problem exists in the Slavianka Mts. as well, where Bondev (1991) indicated the communities of Sesleria korabensis as largely distributed. All the existing - and reviewed by us - Sesleria sp. herbarium materials from the herbariums in the Bulgarian Academy of Sciences and Sofia University, as well as the materials that we gathered, belong to Sesleria rigida subsp. achtarovii and Sesleria latifolia (at lower altitude). The only exceptions are two herbarium specimens, which were determined as Sesleria korabensis, but from 1500-1800 m altitude.

The question regarding the syntaxonomic relations between the subalpine grasslands in the high mountains from the geographical area of Macedonia (Bulgaria, Greece and FYROM) is still open. Still, the existence of syntaxonomical vicariants on isolated grassland "islands" should be adopted.

\section{ORIGIN OF \\ INVESTIGATED VEGETATION IN THE SLAVIANKA MTS.}

The analysis of the biological spectrum (Figure 9) of the plant life-forms demonstrates that it is a typical one for the subalpine grasslands in oro-Mediterranean mountains in the middle of Balkan Peninsula. Together with the high participation of typical Mediterranean geoelements (Figure 10), there are $25 \%$ endemics. Some of these are Balkan endemics: Viola perinensis (38\%), Campanula (Petcovia) orphanidea (25\%), Sesleria rigida subsp. achtarovii (89 \%), Centaurea parilica (29\%) etc. There are also some local Bulgarian endemics, such as Bromus parilicus, Alyssum montanum subsp. regis-borisii, Silene flavescens subsp. stojanovii, Pulsatilla slaviankae and Aubrieta columnae subsp. pirinica. Most of the Balkan endemics are distributed also in the subalpine parts of the mountains in South-western Bulgaria, central Northern Greece and Southern Macedonia - Mt. Pirin, Rhodopes Mts., Menikion Mts., Pangeo Mts., Falacron Mts., Yakupica Mts., Galitchica Ms., Pelister Mts. etc. The analysis of the flora and the endemics (Stefanović 1996) demonstrates that solely the Slavianka Mts. are the most typical oro-Mediterranean mountains in Bulgaria.

On the other hand, the Slavianka Mts. are located further north than the similiar Northern Greek mountains and are the second highest. And they are different from the mountains in NorthEastern Greece. This difference is a bigger compared with the Macedonian mountains. The influence of the Dinaric Mountains (which are the connection with the Alps and Central Europe) is stronger there (see Stefanović 1996). They have many different plant endemics. These specificities of the flora reflect also on the vegetation, and especially on the high-mountain "island" isolated grassland areas (see Karagiannakidou et al. 1995, Stefanović 1996).

The Balkan endemics (species and subspecies) are not only present within these communities, they also play an important ecological role. Their centre of origin is in the limestone mountains in Northern Greece, South-Western Bulgaria, South-Eastern Serbia and Macedonia, described by Stefanoff (1943) as the Greece-Macedonian centre of endemism. According to Stefanović (1996) there are 116 oro-Mediterranean endemics in the mountains, of which 6 are local ones. Many of these endemic taxa, according to Stefanoff (1943) are conservative endemics, i.e. paleoendemics and relicts, and comparatively fewer of them are variational endemics. The first more important group includes species which were found in the grasslands on the Slavianka Mts.: Petkovia orphanidea; Festucopsis sancta; Centaurea parillica; Galium demissum subsp. demissum; Potentilla apennina subsp. stojanovii; Onobrychis montana subsp. scardica; Saxifraga ferdinandi-coburgi; Erisymum comatum; Alyssum repens subsp. repens; Aubrieta columnae subsp. pirinica. Most of these endemics are distributed mainly in this region, including parts of Macedonia, particularly Serbia and Montenegro, Bulgaria and Northern Greece. Their origin is a result of continuous islolation of their populations on the peaks covering small areas at high altitudes - "island isolation" (Karagiannakidou et al. 2001).

Some other endemics could be added to this group as well. They occur in larger areas in 


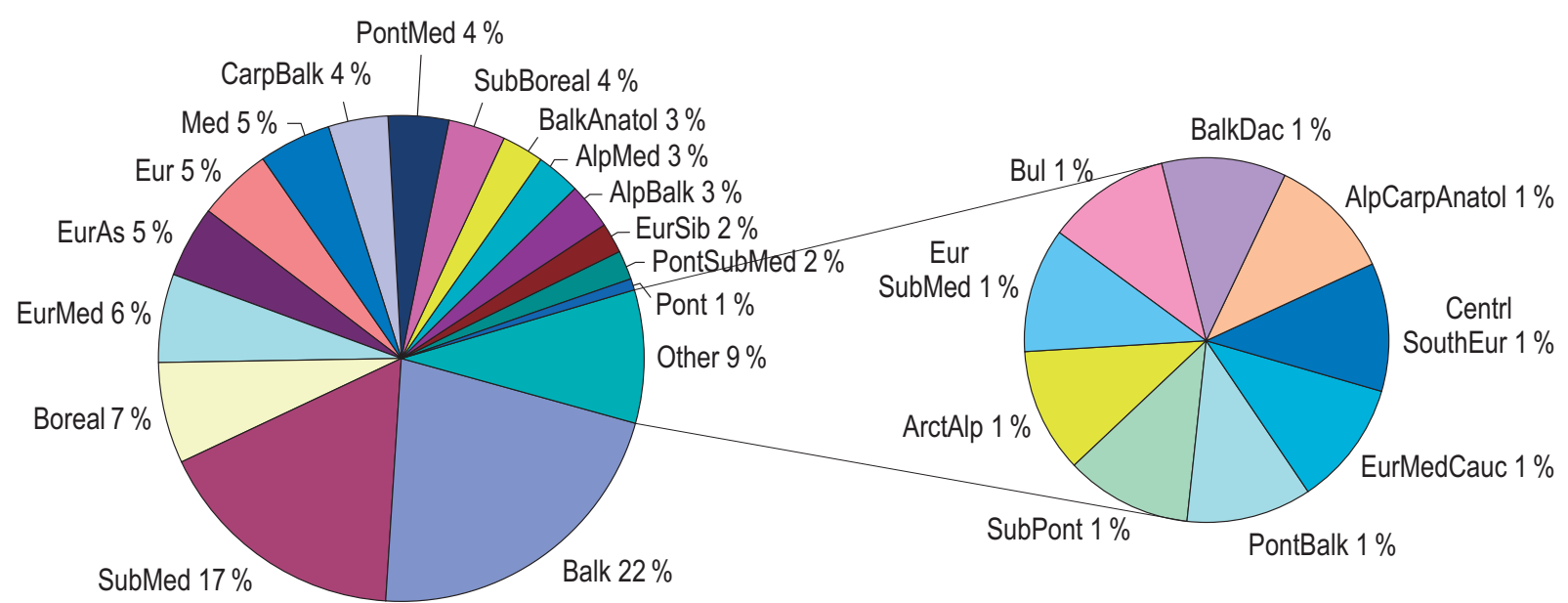

Figure 10: Geographical elements in the florsitic composition of the association Saxifrago ferdinandi-coburgi-Seslerietum achatovii: AlpBalk - Alpic-Balkanian; AlpCarpAnatol - Alpine-Carpathian-Anatolian; AlpMed - Alpine-Mediterranean; ArctAlp - Arctic-Alpine Balk - Balkan endemics; BalkAnatol - Balkan-Anatolian; BalkDac - Balkan-Dacic; Boreal - Boreal; Bul - Bulgarian endemics; CarpBalk - Carpathian-Balkan; CentrSoutEur - Central-South-European; Eur - European; EurAs - European-Asian; EurMed - European-Mediterranean; EurMedCauc - European-Mediterranean-Caucasian; EurSib - European-Siberian; EurSubMed - European-Sub-Mediterranean; Med - Mediterranean; Pont - Pontic (Black sea); PontBalk - Pontic (Black sea)-Balkan; PontMed - Pontic (Black sea)-Mediterranean; PontSubMed - Pontic (Black sea)Sub-Mediterranean; SubMed - Sub-Mediterranean; SubBoreal - Sub-Boreal; SubPont - Sub-Pontic (Black sea).

Slika 10: Deleži geografskih elementov v floristični sestavi asociacije Saxifrago ferdinandi-coburgi-Seslerietum achatovii: AlpBalk - Alpsko-Balkanski; AlpCarpAnatol - Alspko-Karpatsko-Anatolijski; AlpMed - Alpsko-Mediteranski; ArctAlp - Arktično-Alpinski; Balk - Balkanski endemit; BalkAnatol - Balkansko-Anatolijski; BalkDac - Balkansko-Dacijski; Boreal - Borealni; Bul - Bolgarski endemit; CarpBalk - Karpatsko-Balkanski; CentrSoutEur - srednje-južno Evropski; Eur - Evropski; EurAs - Evropsko-Azijski; EurMed - Evropsko-Mediteranski; EurMedCauc - Evropsko-MediteranskiKavkazijski; EurSib - Evropsko-Sibirski; EurSubMed - Evropsko-Submediteranski; Med - Mediteranski; Pont - Pontski (Črno morje); PontBalk - Pontsko (Črno morje)-Balkanski; PontMed - Pontsko (Črno morje)-Mediteranski; PontSubMed - Pontsko (Črno morje)-Submediteranski; SubMed - Submediteranski; SubBoreal - Subborealni; SubPont - Subpontski (Črno morje).

mountain regions of South-Eastern Europe. Most of them are also conservative endemics: Thymus thracicus (44\%); Pedicularis orthantha (41\%); Dianthus microlepis (29\%); Sempervivum leucanthum (44\%); Crocus veluchensis (14\%); Carex kitaibeliana (77\%). All this floristic complex defines the high part of the Slavianka (Alibotush, Orvilos) Mts. as part of one very well presented paleoendemic refuge (a fact, observed as well by Stoyanoff (1941)) and also an old center of endemism, situated in the oro-Mediterranean areas of the southern part of the Balkan Peninsula. This centre of endemism in the Slavianka Mts. comprises not only the highest, but also the medium parts of the mountain and one essential part of it falls into the area of relict oro-Mediterranean Bosnian pine (Pinus heldreichii) forests. In the coniferous belt of this mountain, where conservative endemics dominate Pinus heldreichii and Abies alba subsp. borisii-regis, the paleoendemics like: Viola delphinantha, Convolvulus boissieri subsp. suender- mannii, Crepis schachtii, Bromus parilicus and Festucopsis sancta are also observed. Probably, during the last glacial period, the main refuge zone in the Slavianka Mts. was situated at altitudes between 1000(1200)-1600 m. This zone was at a higher altitude on the Greek and Macedonian mountains, situated further southwards than the Slavianka Mts. The existence of a refuge zone in the mountains of Northern Greece, Bulgaria and Macedonia is confirmed by some palynological studies from Northern Greece and Southwestern Bulgaria (Bozhilova 1986, Tzedakis 1993, 1994, Tzedakis et al. 2002, Jalut et al. 2005). With the improvement of the climatic conditions, the irradiation of these species or their vicariant forms started to the north and also towards the highest sub-alpine belt. This led to the fact that the endemic species and subspecies of oro-Mediterranean origin are mixed with many boreal and arctic-alpine relict taxa like: funiperus pygmaea, Dryas ocopetala, Arctostaphylos uva-ursii and oth- 
ers, which survived on the highest parts of the mountains (Košanin 1924; Stojanoff 1930, Horvat 1952; Stefanović 1996). The present grassland communities in the sub-alpine zone, with their floristic composition, are a result of the mixing of endemics and relicts from the refuge in the contemporary forest belt and preserved glacial relicts in the non-forest zone - the highest part of the mountain. Although in the Slavianka Mts. arctic-alpine geoelements (19\% of the flora) exist, they are less numerous than, for example, on Mt. Pirin (27 \%) and Mt. Rila (35\%) (see Stoyanoff 1941). Their percentage however is higher than in the Northern Greek Mountains (see Karagiannakidou et al. 1995) - Falacron (Bozdag), Pangeo (Kushnica) and the Macedonian mountains (Horvat 1930, 1934, 1949, 1960) - Yakupica, Ostri Vruh and others.

\section{CONCLUSION}

The new association Saxifrago ferdinandi-coburgiSeslerietum achtarovii established in the Slavianka Mts. belongs to the orophyte grasslands in the subalpine belt of the mountains in the South part of the Balkan Peninsula. Its communities are included within the habitat 6170 Alpine and subalpine calcareous grasslands of the Habitat Directive (see Papastergiadou et al. 1997). This habitat is rare in Bulgaria and exists only in a few mountains - Pirin Mts., Central Stara Planina (Balkan Range) Mts. etc. This fact increases the nature conservation value of the subalpine belt in the Slavianka Mts. Many of the typical species in the new association are relicts or endemics- some of them local endemics. They are also protected according to the Bulgarian Biodiversity Act. The Slavianka Mts. are small, but unique mountains, which need special protection. The Alibotush Biosphere Nature Reserve, designated in the mountain, embraces mostly the forested areas, not subalpine grasslands. It is recommended that the strict nature reserve be expanded to include the grassland communities as well. These will ensure better conservation of the diverse vegetation of the Slavianka Mountains.

\section{ACKNOWLEDGEMENTS}

The authors express their special thanks to Assoc. Prof. Dr. Marius Dimitrov (University of Forestry, Sofia) for the technical support, to Chavdar Gus- sev and to Dr. Jonannis Tsiripidis (from the Aristotle University of Thessaloniki) for help with the literature sources and to Dimitrina Boteva for the improving of the English. We would also like to thank many of our colleagues and friends for their help received at different stages of this study.

\section{REFERENCES}

Asyov, B. \& Petrova, A. (eds.): 2006. Conspectus of the Bulgarian vascular flora. Distribution maps and floristic elements. BBF, Sofia. (in Bulgarian).

Barkman, J. J., Doing, H. \& Segal, S. 1964: Kritische Bemerkungen und Vorschlage zur quantitativen Vegetations analyse. - Acta Botanica Neederlandica 13: 394-419.

Bozhilova, E. 1986: Paleoecological conditions and changes in the vegetation in Eastern and Southwestern Bulgaria during the last 15000 years. $\mathrm{PhD}$ thesis. Sofia, 318 pp. (in Bulgarian).

Bondev, I. 1991: The vegetation of Bulgaria. Map in scale $1: 600000$ with explanatory text. Publ. House of Sofia University "St. Kliment Ochridsky". Sofia, 183 pp. (in Bulgarian).

Bondev, I. 2002: Geobotanic regioning. - In: Kopralev, I. (ed.): Geography of Bulgaria. ForKom, Sofia: 336-351. (in Bulgarian).

Braun-Blanquet, J. 1932: Plant sociology: the study of plant communities. McGraw-Hill, New York.

Braun-Blanquet, J. 1964: Pflanzensoziologie. Grundzüge der Vegetationskunde. SpringerVerlag, Wien and New York.

Delipavlov, D., Cheshmedzhiev, I., Popova, M., Terziiski, D. \& Kovachev, I. 2003: Handbook for identification of the plants in Bulgaria. Univ. of Agriculture Publ. House, Plovdiv, 591 pp. (in Bulgarian).

Dryanovski, A. 1934: Flora of the Macedonian Alibotush Mts. IV. Vegetation formations and belts. Personal publishing, Sofia (in Bulgarian).

Georgiev, M. 1991: Physical geography of Bulgaria, Publ. House of Sofia University "St. Kliment Ohridski", Sofia. (in Bulgarian).

Hennekens, S. M. \& Schaminée, J. H. J. 2001: Turboveg, a comprehensive database management system for vegetation data. Journal of Vegetation 1Science 12: 589-591.

Hill, M. O. 1979: TWINSPAN. A FORTRAN program for arranging multivariate data 
in an ordered two-way table by classification of individuals and attributes. Ecology and Systematics, Cornell Univ., Ithaca, New York.

Horvat, I. 1930: Vegetacijske studije u hrvatskim planinama. I. Zadruge na planinskim goletima. Rad JAZU 238, 1-96.

Horvat. I. 1934: Das Festucion pungentis - eine südost-alpinillyrische vegetatione einheit. Acta Bot. Inst. Bot. Univ. Zagreb 9: 54-67.

Horvat, I. 1935: Iztraživanje vegetacije planina Vardarske banovine. 1. Ljet. Jug. Akad. Zn. umj. Zagreb. 47: 142-160.

Horvat, I. 1949: Nauka o biljnim zajednicama. Zagreb, Nakl. Zav. Hrvatska.

Horvat, I. 1952: Prilog poznavanju raširenja nekih planinskih biljaka u jugoistočnoj Evropi. Godišnjak Biološkog Instituta u Sarajevu 5, 199-218.

Horvat, I. 1960: Planinska vegetacija Makedonije u svijetlu suvremenih istraživanja. Acta Musei Macedon. Scient. Nat. 6: 163-203.

Horvat, I., Glavać, V. \& Ellenberg, H. 1974: Vegetation Südosteuropas. Geobotanica selecta, 4. VEB Gustav Fischer Verlag, Jena.

Jalut, G., Carrion, J., David, P., Gonzales-Samperiz, P., Sanchez Goni, M., Tonkov, S. \& Willis, K. 2005: The vegetation around the Mediterranean basin during the last glacial maximum and the Holocene climatic optimum. - In: Petit-Mair, N. \& Vrielinck B. (eds.): The Mediterranean basin: The last two climatic extremes. Explanatory notes of the maps (scale 1/5000000). MMSH and ANDRA. Aix en Provence: $37-57$.

Karagiannakidou, V. 1994: Contribution to the study of mountain-subalpine grassland vegetation of Mount Menikion, north eastern Greece. Ecol. Medit. 20 (3-4): 73-84.

Karagiannakidou, V., Dimopoulos, P. \& Papademetriou, K. 2001: Phytosociological researches on the montane and high-altitude grasslands of North Eastern Greece: Mount Pangeon. Fitosociologia 38(1): 25-54.

Karagiannakidou, V., Konstantinou, M. \& Papademetriou, K. 1995: Floristic and phytogeographical research on the upper montane and the subalpine grassland flora of East Macedonia, Greece. Feddes Repertorium 106 (3-4): 193-213.

Krebs, C. 1999: Ecological methodology. 2 ed. Benjamin/Cummings, Menlo Park, California, 420 pp.

Košanin, N. 1924: Geološki i geografski elementi u razviču flore Južne Srbjie. Zborn. Rad. Posvečen Jovanu Cvjijcu 1924: 591-604.

Lakušić, R 1966: Vegetacija livada i pašnjaka na planini Bjelasici. Godišnjak Biološkog Instituta Sarajevo, 19: 25-186.

Meusel, H., Jäger E. \& Meiner, E. 1965: Vergleichende chorologie der Zentral europaischen Flora, VEB, Gustav Fischer Verlag, Jena.

Mucina, L., Valachovič, M., Jarolímek, I., Šeffer, J., Kubinská, A. \& Pišút, I. 1990: The vegetation of rock fissures, screes, and snow-beds in the Pirin Planina Mountains (Bulgaria). Studia Geobotanica 10: 15-58.

Mueller-Dombois, D. \& Ellenberg, H. 1974: Aims and methods of vegetation ecology. Wiley, London.

Ninov, N. 2002: Soils. - In: Kopralev, I. (ed.): Geography of Bulgaria. Physical geography. Socio-economic geography. ForKom, Sofia: 277-315 (in Bulgarian).

Ohba, T. 1974: Vergleichende Studien über die alpine Vegetation Japans. 1. Carici rupestris-Kobresietea bellardii. Phytocoenologia 1: 339-401.

Oriolo, G. 2001: Naked rush swards (OxytropidoElynion Br.-Bl. 1949) on the Alps and the Apennines and their syntaxonomical position. Fitosociologia 38: 91-101.

Papastergiadou, E., Dafis, S., Dimopoulos, P. \& Lazaridou Th. 1997: Syntaxonomic typology of Greek Habitats. Folia Geobotanica et Phytotaxonomica 32: 335-341.

Petrík, A., Šibík J. \& Valachovič M. 2005: The class Carici rupestris-Kobresietea bellardii Ohba 1974 also in the Western Carpathians. Hacquetia 4(1): 33-51.

Podani, J. 2002: SYN-TAX-pc. Computer Programs for Multivariate data Analysis in Ecology and Systematics. Scientia Publishing, Budapest: 53 pp.

Quezel, P. 1967: La vegetation des hauts sommets du Pinde et l' Olympe de Thessalie. Vegetatio 14: $127-228$.

Quézel, P. 1989: Contribution à l'étude phytosociologique des pelouses ecorchées culminales du massif du Falakron. Bios: 187-193.

Rajevski, L. 1990: Fitocenološke karakteristike planinskih pašnjaka severnog dela Šarplanine. Glasnik Instituta i Botaničke Bašte Univerziteta u Beogradu 9: 1-62.

Raunkiaer, C. 1934: Life form of plants and statistical plant geography. Clarendon Press. New York - London.

Raus, T. 1987: Gipfel Vegetation des Ossa Gebirg- 
es im Vergleich zum Olymp (Thessalien, Griechenland). Munstersche Geor. Arbeiten 27: 199-206.

Rodwell, J. S., Schaminée, J. H. J., Mucina, L., Pignatti, S., Dring, J. \& Moss, D. 2002: The Diversity of European Vegetation. An overview of the phytosociological alliances and their relationships to EUNIS habitats. Wageningen. $168 \mathrm{pp}$.

Schreiber, H. J. 1998: Waldgrenznahe Buchenwälder und Grasländer des Falakron und Pangäon in Nordostgriechenland. Syntaxonomie, Struktur und Dynamik. Arb. Inst. Landschaftsökol. Westf. Wilhelms-Univ. Münster 4: 1-171.

Simon, T. 1958: Über die alpinen Pflanzengesellschaften des Pirin-Gebirges. Acta Bot. Acad. Sci. Hung. 4(1-2): 159-189.

Stefanoff, B. 1943: Phytogeographische Elemente in Bulgarien. Proc. of Bull. Acad. Sci. 39, 506 pp. (in Bulgarian).

Stefanović, V. 1996: Analysis of the Central European and Mediterranean orophytic element on the mountains of the West and Central Balkan Peninsula, with special reference to endemics. Bocconea 5: 77-97.
Stoyanoff, N. 1922: On the vegetation of Ali-Botush Mts. Ann. Univ. Sofia, Fac. PhysicoMathematique 17: 1-35. (in Bulgarian).

Stojanoff, N. 1930: Versuch einer Analysedes relicten Elements in der Flora der Balkanhanbinsel. Bot. Jahrb. Syst. 63: 368-418.

Stoyanoff, N. 1941: Versuch einer phytozoenologishen Charakteristik Bulgariens. Ann. Univ. Sofia, Fac. Physico-Mathematique 34(3): 93184. (in Bulgarian).

Stojanoff, N. \& Stefanoff, B. 1922: Phytogeographische und floristische Charakteristik des Pirin-Gebirges. Ann. Univ. Sofia, Fac. PhysicoMathematique 18: 1-27. (in Bulgarian).

Tichý, L. 2002: JUICE, software for vegetation classification. Journal of Vegetation Science 13: 451-453.

Tzedakis, P. C. 1993: Long-term tree populations in northwest Greece through multiple Quaternary climatic cycles. Nature 364: 437-440.

Tzedakis, P. C. 1994: Vegetation change through glacial-interglacial cycles: a long pollen sequence perspective. Philosophical Transactions of the Royal Society of London B 345: 403-432.

Tzedakis, P. C., Lawson, I. T., Frogley, M. R.,

Table 1: Diagnostic table of a new grassland association Saxifrago ferdinandi-coburgi-Seslerietum achtarovii ass. nova from the Slavianka Mts.

\begin{tabular}{|c|c|c|c|c|c|c|c|c|c|c|c|c|c|c|}
\hline Number of releves & 1 & 2 & 3 & 4 & 5 & 6 & 7 & 8 & 9 & 10 & 11 & 12 & 13 & 14 \\
\hline Plot sample area $\left(\mathrm{m}_{\iota}\right)$ & 100 & 100 & 100 & 100 & 100 & 100 & 100 & 100 & 100 & 100 & 100 & 100 & 100 & 100 \\
\hline Altitude (m) X 10 & 215 & 195 & 217 & 205 & 205 & 210 & 115 & 220 & 205 & 220 & 210 & 205 & 210 & 215 \\
\hline Exposition & $\mathrm{NE}$ & $\mathrm{NE}$ & NW & $\mathrm{NE}$ & $\mathrm{NE}$ & $\mathrm{NE}$ & W & 0 & 0 & $\mathrm{E}$ & $\mathrm{NE}$ & $\mathrm{NE}$ & $\mathrm{N}$ & $\mathrm{E}$ \\
\hline Slope (in degrees) & 70 & 5 & 30 & 45 & 35 & 10 & 30 & 0 & 0 & 0 & 40 & 50 & 45 & 50 \\
\hline Coverage (\%) & 20 & 50 & 50 & 45 & 50 & 50 & 55 & 30 & 50 & 40 & 45 & 50 & 55 & 50 \\
\hline
\end{tabular}

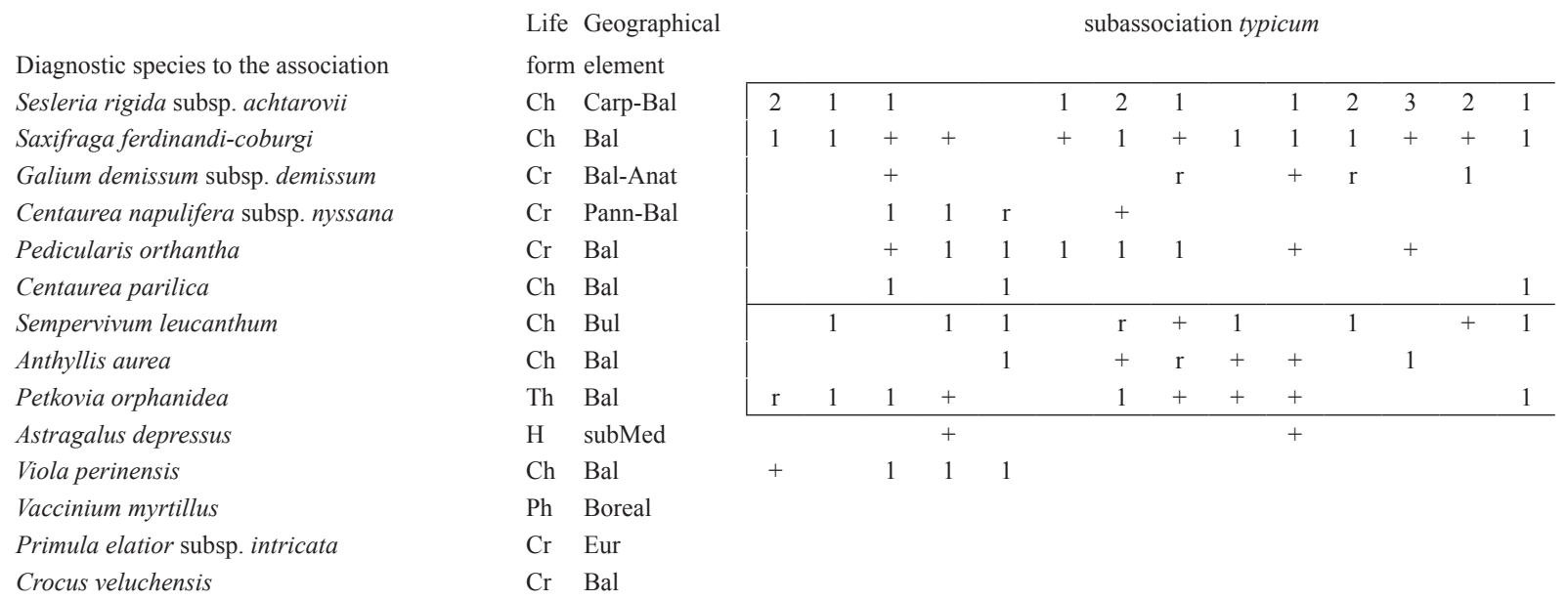


Hewitt, G. M. \& Preece, R. C. 2002: Buffered Tree Population Changes in a Quaternary Refugium: Evolutionary Implications. Science 297: 2044-2047.

Tzonev, R., Dimitrov, M. \& Roussakova, V. 2009: Syntaxa according to the Braun-Blanquet approach in Bulgaria. Phytologia Balcanica 15 (2): 209-233.

Vaptzarov, I., Velev, S., Yordanova, M \& Gorunova, D. 1989: Rila-Rhodope area. In: Mishev, K. (ed.): Geography of Bulgaria. Vol. 3. Physico-geographic and social-economic regioning in Bulgaria. BAS: pp. 166-219.

Velchev, V. \& Bondev, I. 1984a: Endangered and rare plants communities in Bulgaria. In $\_\mathrm{Au}$ thor: Contemporary theoretic and applicable aspects in plant ecology, BAS, Sofia, Vol. 1: 94-105 pp. (in Bulgarian).

Velchev, V. \& Bondev, I. 1984b: Participation of Bulgarian and Balkan endemics in the vegetation of Bulgaria. In Author: Contemporary theoretic and applicable aspects in plant ecology, BAS, Sosia, Vol. 1: 85-93. (in Bulgarian).

Velchev, V. \& Tonkov, S. 1986: Vegetation and flora of Southwestern Bulgaria. In: Botyov, B. (ed.): Fauna of Southwestern Bulgaria. Sofia. BAS: 20-42. (in Bulgarian)

Velev, S. 2002. Climatic regioning. In: Kopralev, I. (ed.): Geography of Bulgaria. Physical geography. ForCom, Sofia: 155-156 (in Bulgarian).

Weber, H., Moravec, J. \& Theurillat, J.-P. 2000: International Code of Phytosociological Nomenclature. $3^{\text {rd }}$ edition. Jornal of Vegetation Science 11: 739-768.

Westhoff, V. \& Maarel, E. 1973: The Braun-Blanquet's approach. In: Whittaker, R. (ed.): Handbook of Vegetation Science. Ordination and Classification of Vegetation. The Hague, p. 619-726.

Westhoff, V \& Maarel, E. 1979: Transformation of cover-abundance values in phytosociology and its effect on community similarity. Vegetatio 39: 97-114.

Tabela 1: Diagnostična tabela nove travniške asociacije Saxifrago ferdinandi-coburgi - Seslerietum achtarovii ass. nova z gorovja Slavjanka.

\begin{tabular}{|c|c|c|c|c|c|c|c|c|c|c|c|c|c|c|c|c|c|c|c|c|c|c|c|c|c|c|}
\hline 15 & 16 & 17 & 18 & 19 & 20 & 21 & 22 & 23 & & 24 & 25 & 26 & 27 & 28 & 29 & 30 & 31 & 32 & 33 & 34 & 35 & 36 & 37 & 38 & & \\
\hline 100 & 100 & 100 & 100 & 100 & 100 & 100 & 100 & 100 & & 100 & 100 & 100 & 100 & 100 & 100 & 100 & 100 & 100 & 100 & 100 & 100 & 100 & 100 & 100 & & \\
\hline 210 & 205 & 210 & 210 & 205 & 218 & 210 & 200 & 200 & $\bar{J}$ & 195 & 205 & 190 & 210 & 200 & 215 & 210 & 210 & 215 & 195 & 210 & 200 & 190 & 210 & 221 & & \\
\hline $\mathrm{E}$ & $\mathrm{NE}$ & $\mathrm{NE}$ & $\mathrm{N}$ & SE & SW & SW & $\mathrm{N}$ & NW & 至 & $\mathrm{NE}$ & E & $\mathrm{N}$ & $\mathrm{N}$ & $\mathrm{NE}$ & E & W & E & E & $\mathrm{N}$ & $\mathrm{N}$ & SW & $\mathrm{N}$ & W & $\mathrm{N}$ & & \\
\hline 35 & 30 & 5 & 5 & 45 & 10 & 50 & 45 & 40 & & 10 & 50 & 45 & 40 & 5 & 15 & 40 & 45 & 40 & 50 & 30 & 40 & 15 & 15 & 20 & & \\
\hline 45 & 60 & 50 & 60 & 40 & 40 & 75 & 60 & 50 & & 90 & 40 & 50 & 80 & 80 & 80 & 80 & 70 & 65 & 90 & 50 & 50 & 70 & 70 & 55 & & \\
\hline
\end{tabular}

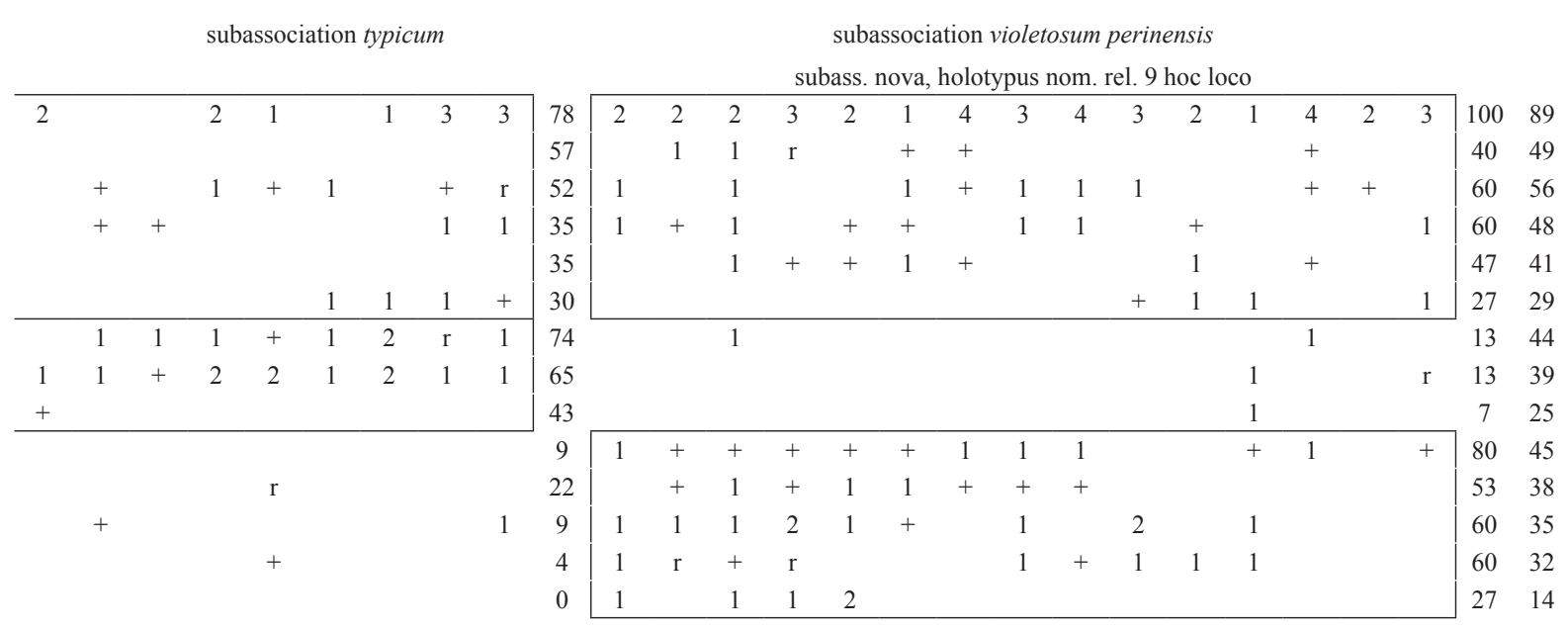


Number of releves

$\begin{array}{llllllllllllll}1 & 2 & 3 & 4 & 5 & 6 & 7 & 8 & 9 & 10 & 11 & 12 & 13 & 14\end{array}$

Diagnostic species to the alliance Edraiantho-Seslerion Horvat 1949 and order Onobrychido-Seslerietalia Horvat 1949

Dianthus microlepis

$\mathrm{Ch} \quad \mathrm{Bal}$

Achillea ageratifolia

Paronychia kapela

$\mathrm{Ch} \mathrm{Bal}$

Dryas octopetala

H subMed

Potentilla apennina subsp. stojanovii

H Boreal

Euphrasia salisburgensis

H Ap-Bal

Th subMed

1

$+\quad 1$

$1+$

11

1

(2)

Diagnostic species to the class Elyno-Seslerietea Braun-Blanq. 1948

Carex kitaibeliana

Ch subMed

Androsace villosa

Globularia cordifolia

Festucopsis sancta

Anthyllis montana subsp. jacquinii

Senecio papposus subsp. papposus

Draba aizoides

Onobrychis montana subsp. scardica

Poa alpina

Linum alpinum subsp. alpinum

Minuartia verna

Cr Arct-Alp

H Alp-Carp-Anat

Ch Bal

Ch Alp-Med

Ch Carp-Bal

Ch Bal

Ch Carp-Bal

Ch Boreal

Ch Alp-Med

Ch subBoreal

Diagnostic species to the class Dapho-Festucetea Quezel 1964, order Daphno-Festucetalia Quezel 1964 and alliance Astragalo-Seslerion Quezel 1964

Rhodax canus

Thymus thracicus

Astragalus angustifolius subsp. pungens

Teucrium montanum

Daphne oleoides

Other species

Juniperus pygmaea

Hieracium pseudopillosella

Taraxacum pindicola

Muscari botryoides

Trinia glauca subsp. glauca

Gentiana verna

Saxifraga sempervivum

$\mathrm{H}$ Pont

Ch subMed

$\mathrm{Ph}$ subMed

Ch subMed

$\mathrm{Ph}$ subMed

Chamaecytisus absinthioides subsp. absintioides $\mathrm{Ph} \quad \mathrm{Bal}$

Rhinanthus wagneri

Pinus heldreichii

Teucrium chamaedrys

Veronica chamaedrys

Arctostaphylos uva-ursi

Jurinea mollis

Erisymum comatum

Corydalis solida

Luzula luzuloides

Alyssum repens subsp. repens

Sedum acre

Trifolium montanum

Dactylorhiza sambucina

Euphorbia amygdaloides

Scabiosa sp.

Botrychium lunaria

Ranunculus montanus

Aubrieta columnae subsp. pirinica

Doronicum columnae

Polygala acarnanica

Myosotis sp.

Teucrium polium

Syntrichia sp.
$\mathrm{Ph}$ Med

$\mathrm{Ch}$ Med

Ch Bal

$\mathrm{Cr}$ Med

Ch subMed

Ch Eur-As

$\mathrm{Ch} \mathrm{Bal}$

Ch subMed

$\mathrm{Ph}$ Ap-Bal

Ch subMed

Ch Eur-As

$\mathrm{H}$ Boreal

Ch Pont-Med

Th Bal

$\mathrm{Cr}$ Eur-Med-Cas

$\mathrm{Ch}$ Eur

$\mathrm{H}$ Eur

$\mathrm{Ch}$ Eur-Med

Ch Spont

$\mathrm{Cr}$ Eur

$\mathrm{Ch}$ Eur

Th

Ch Boreal

Ch subMed

$\mathrm{Ch}$ Bal

Ch Pont-Med

$\mathrm{Ch}$ Bal

$\mathrm{Ch}$

Ch Pont-Med

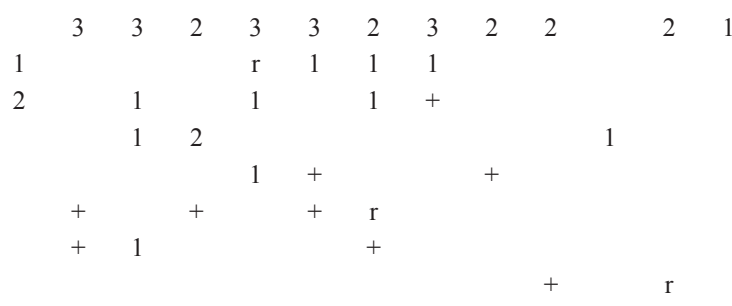


T. Karakiev \& R. Tzonev: SaXifrago Ferdinandi-CobUrgi-SesLerietum aCtarovi - a new association from Slavianka Mts. \begin{tabular}{llllllllllllllllllllllllll}
15 & 16 & 17 & 18 & 19 & 20 & 21 & 22 & 23 & Freq. & 24 & 25 & 26 & 27 & 28 & 29 & 30 & 31 & 32 & 33 & 34 & 35 & 36 & 37 & 38 & Freq. Total \\
\hline
\end{tabular}

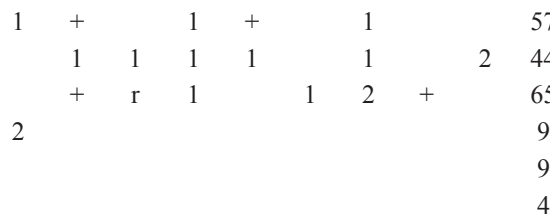

\begin{tabular}{|c|c|}
\hline \multirow{6}{*}{+} & 0 \\
\hline & 7 \\
\hline & 7 \\
\hline & 0 \\
\hline & 0 \\
\hline & 0 \\
\hline
\end{tabular}

\begin{tabular}{|c|c|c|c|c|c|c|c|c|c|c|c|c|c|c|c|c|c|c|c|c|c|c|}
\hline 33 & 3 & 2 & 2 & 2 & 74 & 3 & 1 & 2 & 1 & 3 & + & 1 & & 1 & 2 & 2 & 2 & & 3 & & 80 & 77 \\
\hline 1 & + & & & & 35 & & & & & & & & & & & & & 2 & + & & 13 & 24 \\
\hline \multirow[t]{3}{*}{1} & & & & & 26 & & & & & & & & & & & & & & & & 0 & 13 \\
\hline & & & & & 13 & 1 & & & & & & & 1 & & & & 1 & & 1 & + & 33 & 23 \\
\hline & & & & & 13 & & & & & & & & & & & & & & + & 1 & 13 & 13 \\
\hline $\mathrm{r}$ & & & & + & 26 & 2 & + & & 1 & & + & & & & 1 & 1 & & & & & 40 & 33 \\
\hline \multirow[t]{2}{*}{+} & & & & & 22 & & & & & & & & & & & & & & & & 0 & 11 \\
\hline & & & & & 9 & & & & & & & & & & & & & & & & 0 & 5 \\
\hline \multirow[t]{2}{*}{1} & & 1 & & & 17 & 1 & & & & & & & & & & & & & & & 7 & 12 \\
\hline & & & & & 0 & & & & & & & & & + & & & & $\mathrm{r}$ & & & 13 & 7 \\
\hline 1 & & & & & 4 & & & & & & & & & & & & & & & & 0 & 2 \\
\hline
\end{tabular}

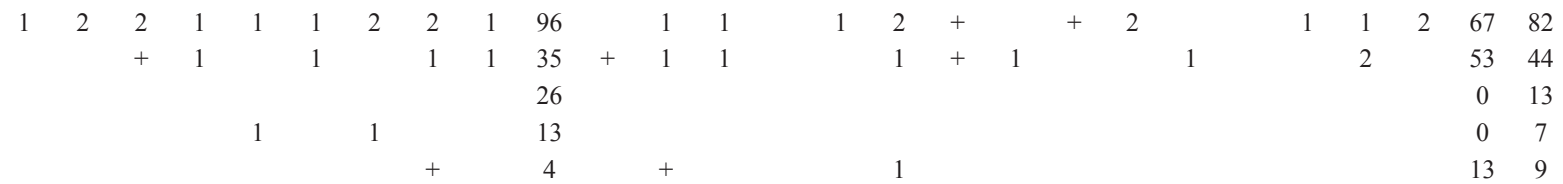

\begin{tabular}{|c|c|c|c|c|c|c|c|c|c|c|c|c|c|c|c|c|c|c|c|c|c|c|c|c|c|}
\hline 1 & & & 2 & & & + & & 70 & 2 & 2 & 2 & 2 & 1 & + & & 2 & $\mathrm{r}$ & & 1 & + & $\mathrm{r}$ & & + & 80 & 75 \\
\hline 1 & 1 & & & 1 & 1 & + & & 52 & & & 1 & 1 & 1 & 1 & 1 & + & + & & & 1 & & & & 53 & 53 \\
\hline+ & + & $\mathrm{r}$ & & & & & & 22 & & + & 1 & 1 & + & + & & 1 & + & 1 & 1 & 1 & + & + & & 80 & 51 \\
\hline & 1 & & & & & & & 4 & 1 & 1 & 1 & 1 & 1 & 1 & 1 & + & 1 & & & & 1 & & & 67 & 36 \\
\hline & + & 1 & & & & & & 30 & $\mathrm{r}$ & & & & 1 & + & & $\mathrm{r}$ & & & & & & + & & 33 & 32 \\
\hline & & & & & & & & 17 & & & 1 & 1 & 1 & 1 & 1 & & & & & & 1 & 1 & 1 & 53 & 35 \\
\hline & + & & & & & & & 30 & & + & & & & & & & & & & & $\mathrm{r}$ & 1 & + & 27 & 29 \\
\hline & & & & & & 1 & & 9 & 1 & & & & + & $\mathrm{r}$ & & $\mathrm{r}$ & 1 & 1 & & 1 & & & & 47 & 28 \\
\hline+ & & & & 1 & 1 & 1 & 1 & 26 & & & & & & & & & & $\mathrm{r}$ & 1 & & & & & 13 & 20 \\
\hline $\mathrm{r}$ & & & & & & & & 17 & & $\mathrm{r}$ & + & & & & & $\mathrm{r}$ & & & & & & & & 20 & 19 \\
\hline & & & & & & + & + & 17 & 1 & & & & & & & 1 & + & & & & & & & 20 & 19 \\
\hline & & & 1 & & & & & 4 & & & 1 & 1 & 1 & & + & & & & & & & & & 27 & 16 \\
\hline 1 & & & & & & & & 17 & & & & & & & & & & & & & 2 & & & 7 & 12 \\
\hline & & & & & $\mathrm{r}$ & & & 4 & 1 & & & & & + & & & & & & 1 & & & & 20 & 12 \\
\hline & & & & & & & & 9 & & & & & & & & & & & & & $\mathrm{r}$ & & + & 13 & 11 \\
\hline & & & & & & & & 0 & 1 & 1 & + & 1 & & & & & & & & & & & & 27 & 14 \\
\hline & & & & & & & & 0 & + & & & $\mathrm{r}$ & & & & $\mathrm{r}$ & & 1 & & & & & & 27 & 14 \\
\hline & 1 & + & & & & & & 13 & & & & & & & & & & & & & + & & & 7 & 10 \\
\hline & & & & & & + & & 9 & & 1 & & & & & & & & & & & & & & 7 & 8 \\
\hline & & & 1 & & & & & 4 & + & & & & & & & & + & & & & & & & 13 & 9 \\
\hline+ & & & & & & & & 4 & & & & $\mathrm{r}$ & & & & & & & & & & + & & 13 & 9 \\
\hline & & & & & & & & 0 & & & + & & & & & $\mathrm{r}$ & & & & & & & & 13 & 7 \\
\hline & & & & & & & & 0 & & & + & & & + & & & & & & & & & & 13 & 7 \\
\hline & & & & & & & & 0 & $\mathrm{r}$ & & & & & $\mathrm{r}$ & & & & & & & & & & 13 & 7 \\
\hline & & & & & & & & 0 & + & & + & & & & & & & & & & & & & 13 & 7 \\
\hline & & & & & & & & 9 & & & & & & & & & & & & & & & & 0 & 5 \\
\hline & & & & & & & & 0 & & & 1 & + & & & & & & & & & & & & 13 & 7 \\
\hline & & & & & & & & 4 & & & & & & & & & & & & & $\mathrm{r}$ & & & 7 & 6 \\
\hline & & & & & & & & 0 & $\mathrm{r}$ & & & & & 1 & & & & & & & & & & 13 & 7 \\
\hline & & & & & & & & 4 & & & & & & & & & & & & & & & & 0 & 2 \\
\hline & & & & & & & & 4 & & & & & & & & & & & & & & & & 0 & 2 \\
\hline
\end{tabular}


Table 2: Synoptic table of related syntaxa with Slavianka Mt. phytocoenoses.

Tabela 2: Sinoptična tabela sintaksona z združbami s Slavjanke.

\begin{tabular}{|c|c|c|c|c|c|c|c|c|c|c|}
\hline & 1 & 2 & 3 & 4 & 5 & 6 & 7 & 8 & 9 & 10 \\
\hline Sesleria rigida subsp. achtarovii & IV & $\mathrm{V}$ & $\mathrm{V}$ & & & III & & & IV & \\
\hline Saxifraga ferdinandi-coburgi & III & II & III & & & & & IV & & \\
\hline Galium demissum subsp. demissum & III & II & III & & & & & & & \\
\hline Centaurea napulifera subsp. nyssana & II & II & III & & & & & & & \\
\hline Pedicularis orthantha & II & II & II & & & & & & & \\
\hline Centaurea parilica & II & II & II & & & & IV & & & \\
\hline Sempervivum leucanthum & IV & $\mathrm{I}$ & III & & & & & & & \\
\hline Anthyllis aurea & IV & I & III & II & II & & $\mathrm{V}$ & $\mathrm{V}$ & II & \\
\hline Petkovia orphanidea (Campanula orphanidea) & III & $\mathrm{I}$ & II & & & & $\mathrm{I}$ & & III & \\
\hline Astragalus depressus & I & IV & II & & & & & & & \\
\hline Viola perinensis & I & III & II & & & & & & & \\
\hline Vaccinium myrtillus & I & III & II & & & & & & & \\
\hline Primula elatior subsp. intricata & I & IV & II & & & & & & & \\
\hline Crocus veluchensis & & II & $\mathrm{I}$ & & & & & & & \\
\hline Dianthus microlepis & III & I & II & & & & & & & \\
\hline Achillea ageratifolia & III & I & II & IV & II & & & & I & \\
\hline Paronychia kapela & IV & I & III & $\mathrm{V}$ & IV & & & & & III \\
\hline Dryas octopetala & I & & I & II & II & & & & & \\
\hline Carex kitaibeliana (Carex laevis) & IV & IV & IV & $\mathrm{V}$ & $\mathrm{V}$ & & $\mathrm{V}$ & IV & & \\
\hline Androsace villosa & II & I & II & & & & & IV & & \\
\hline Globularia cordifolia & II & I & I & $\mathrm{V}$ & II & & & & & III \\
\hline Festucopsis sancta & I & II & II & & & & $\mathrm{V}$ & & $\mathrm{I}$ & \\
\hline Anthyllis montana subsp. jacquinii & I & I & I & & & & & IV & & \\
\hline Senecio papposus subsp. papposus & II & II & II & & & & & & & \\
\hline Draba aizoides & II & I & I & & & & & & & \\
\hline Onobrychis montana subsp. scardica & I & & I & IV & III & III & & & I & \\
\hline Poa alpina & I & I & I & II & II & & & III & III & \\
\hline Minuartia verna & I & & I & & III & & & & IV & $\mathrm{V}$ \\
\hline Rhodax canus (Helianthemum canum) & $\mathrm{V}$ & IV & $\mathrm{V}$ & & & & III & V & IV & \\
\hline Thymus thracicus & II & II & III & & & IV & IV & III & & \\
\hline Astragalus angustifolius subsp. pungens & $\mathrm{I}$ & $\mathrm{I}$ & I & & & II & & & $\mathrm{V}$ & \\
\hline Teucrium montanum & I & & I & & & & II & & III & III \\
\hline Daphne oleoides & I & I & I & & & III & & & I & \\
\hline Juniperus pygmaea & IV & IV & IV & & & & & & & \\
\hline Hieracium pseudopillosella & III & III & III & & & & & & & \\
\hline Taraxacum pindicola & II & IV & III & & & & & & & \\
\hline Muscari botryoides & I & IV & II & & & & & & & \\
\hline Trinia glauca subsp. glauca & II & II & II & & & & & & & \\
\hline Gentiana verna & I & II & II & II & III & & & & & \\
\hline Saxifraga sempervivum & II & II & II & & & & & & II & \\
\hline Chamaecytisus absinthioides subsp. absintioides & I & III & II & & & & & & & \\
\hline Rhinanthus wagneri & II & I & II & & & & & & & \\
\hline Veronica chamaedrys & I & II & I & & & & & & & \\
\hline Corydalis solida & & II & I & & & & & & & \\
\hline Luzula luzuloides & & II & I & & & & & & & \\
\hline Asperula aristata subsp. longiflora (Asperula longiflora) & I & & I & II & II & & & & & \\
\hline
\end{tabular}




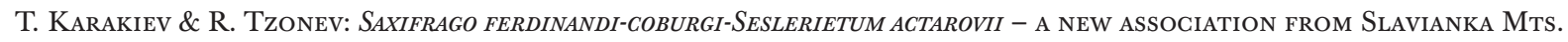

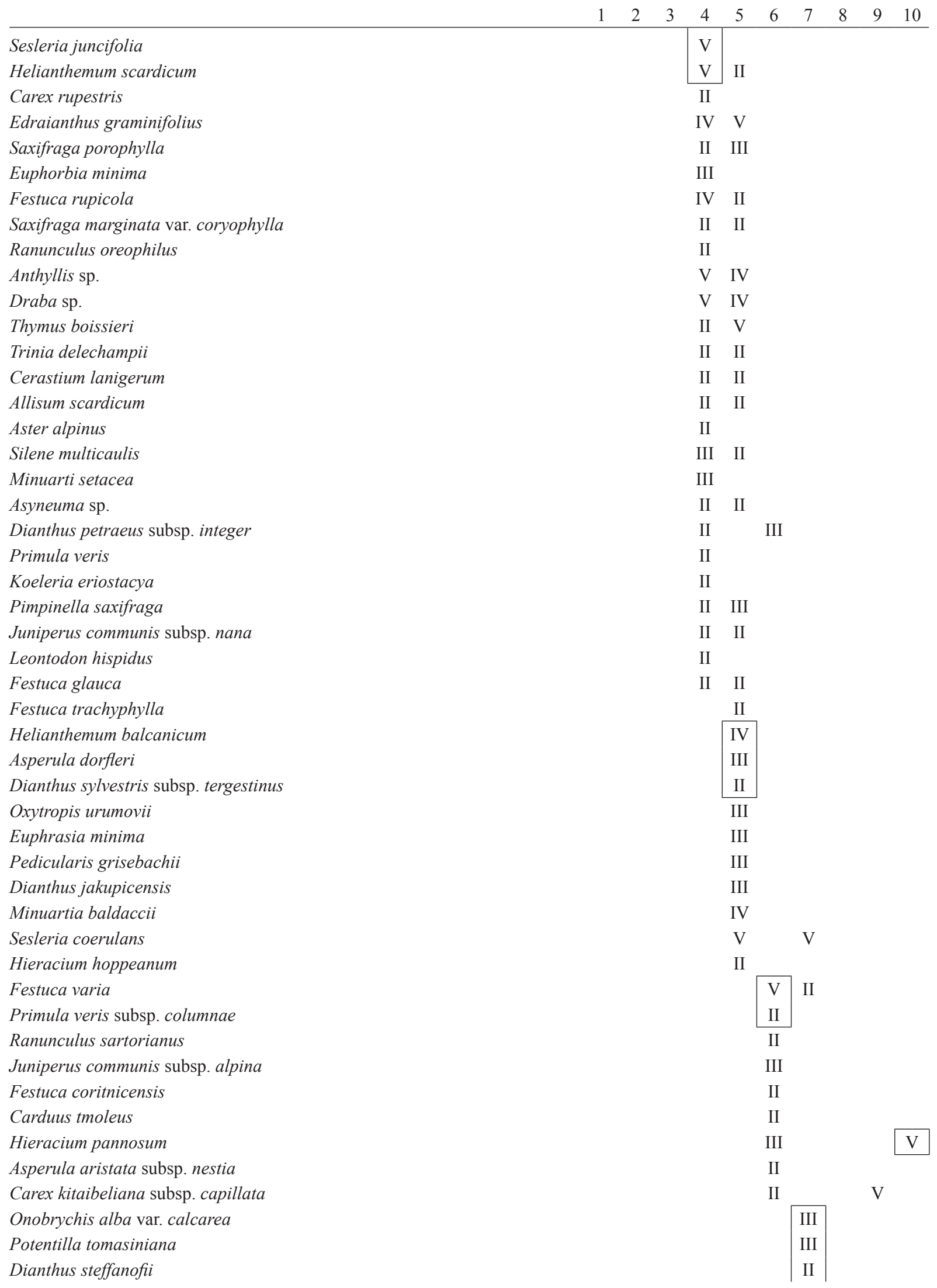


Scabiosa rodopensis

Genista rhodopea

Origanum vulgare var. viride

Linum tauricum

Saponaria bellidifolia

Artemisia cf. campestris

Chondrilla urumoffii

Achillea ageratifolia subsp. aizoon

Sideritis scardica

Juniperus hemisphaerica

Globularia meridionalis

Stipa pulcherrima

Peucedanum longifolium

Festuca ovina subsp. duriuscula

Hypericum rumelicum

Astragalus tymphresteus

Onosma taurica

$\begin{array}{llllll}1 & 2 & 3 & 4 & 5 & 6\end{array}$

Asperula aristata subsp. tessala

Jurinea arachnoidea

Phalangium liliago

Gladiolus iliricus

Orchis pyramidalis

Thalictrum minus

Viola delphinantha

Festuca panciciana

Linum tracicum

Anthyllis vulneraria var. pulchella

Matthiola tristis var. thessala

89

Sempervivum marmoreum

II

II I

II

Festuca macedonica

Thymus cherlerioides

Sesleria tenerrima

Alyssum montanum

Potentilla cinerea

Acinos alpinus subsp. alpinus

Dianthus petraeus subsp. orbelicus

Hypericum olympicum

Coronilla varia

Vincetoxicum hirundinaria subsp. nivale

Thymys sibthorpii

Helianthemum nummularium

Euphorbia myrsinites

Scleranthus annuus

Potentilla argentea

Carex humilis

Paronychia rechingeri

Galium rhodopeum

Silene ciliata

Hipochaeris pelivanovichii 


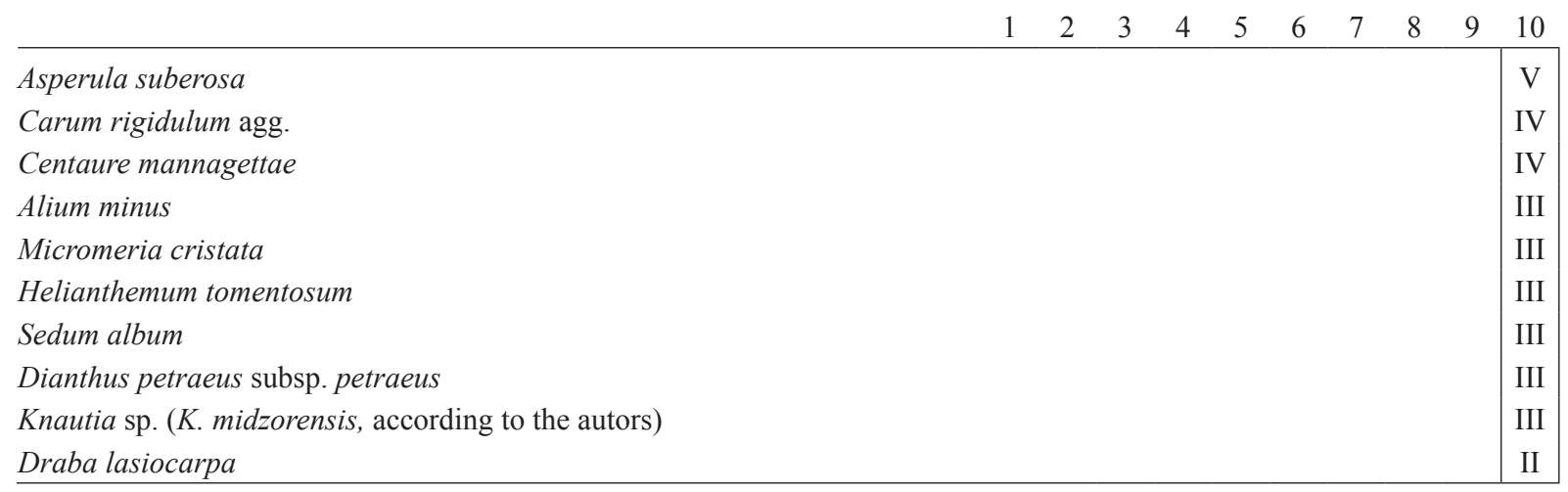

1. Saxifrago ferdinandi-coburgii - Seslerietum achtarovii ass nova subass typicum

2. Saxifrago ferdinandi-coburgii - Seslerietum achtarovii ass nova subass violetosum perinensis

3. Generally about 1 and 2

4. Helianthemo - Seslerietum Horvat 1960 (Yacupica Mt. - Central Macedonia), Acta Musei Macedonici Scient. Nat. 6: 163-203.

5. Edraiantho - Helianthemum balcanici Horvat 1935 (=Carex laevis - Helianthemum balcanicum) (Yacupica Mt. - Central Macedonia), 1. Ljet. Jug. Akad. Zn. umj. Zagreb. 47: 142-160.

6. Seslerio achtarovii - Festucetum variae Karagiannikidou \& al. 2001 (Pangeo Mt. /Kushnica, Parnar dag/ - North Greece), Fitosociologia, 38 (1): 25-54, 2001

7. Agropyro sancti - Centauretum parilicae Quezel 1989 (Falacron Mt. (Bozdag) - North Greece), Bios (Thessaloniki): 187-193.

8. Violo delphinanthae - Saxifragetum ferdinandi-coburgi Quezel 1989 (Falacron Mt. (Bozdag) - North Greece), Bios (Thessaloniki): 187-193.

9. Astragalo pungentis-Caricetum kitaibelianae Karagiannikidou 1994 (Menikion /Zmiinica, Serski Bozdag/ - North Greece) Ecologia Mediterranea XX (3/4) 1994: 73-84

10. Hieracio- Caricetum kitaibelianae Mucina \& al. 1990 (Pirin Mt. - South-Western Bulgaria), Studia Geobotanica, 10: 15-58, 1990.

*The diagnostic species to the associations according to cited authors, are Bold lines 